\title{
The development of extension and magmatism in the Red Sea rift of Afar
}

\author{
Derek Keir ${ }^{\mathrm{a}, *}$, Ian D. Bastow ${ }^{\mathrm{b}, 1}$, Carolina Pagli ${ }^{\mathrm{c}}$, Emma L. Chambers ${ }^{\mathrm{a}}$ \\ a National Oceanography Centre Southampton, University of Southampton, Southampton, SO14 3ZH, UK \\ b School of Earth Sciences, University of Bristol, Bristol, BS8 1RJ, UK \\ c School of Earth and Environment, University of Leeds, Leeds, LS2 9JT, UK
}

\section{A R T I C L E I N F O}

Article history:

Received 4 June 2012

Received in revised form 14 September 2012

Accepted 15 October 2012

Available online 26 October 2012

\section{Keywords:}

Continental breakup

Magma intrusion

Plate stretching

Seaward dipping reflectors

Afar rift

\begin{abstract}
A B S T R A C T
Despite the importance of continental breakup in plate tectonics, precisely how extensional processes such as brittle faulting, ductile plate stretching, and magma intrusion evolve in space and time during the development of new ocean basins remains poorly understood. The rifting of Arabia from Africa in the Afar depression is an ideal natural laboratory to address this problem since the region exposes subaerially the tectonically active transition from continental rifting to incipient seafloor spreading. We review recent constraints on along-axis variations in rift morphology, crustal and mantle structure, the distribution and style of ongoing faulting, subsurface magmatism and surface volcanism in the Red Sea rift of Afar to understand processes ultimately responsible for the formation of magmatic rifted continental margins. Our synthesis shows that there is a fundamental change in rift morphology from central Afar northward into the Danakil depression, spatially coincident with marked thinning of the crust, an increase in the volume of young basalt flows, and subsidence of the land towards and below sea-level. The variations can be attributed to a northward increase in proportion of extension by ductile plate stretching at the expense of magma intrusion. This is likely in response to a longer history of localised heating and weakening in a narrower rift. Thus, although magma intrusion accommodates strain for a protracted period during rift development, the final stages of breakup are dominated by a phase of plate stretching with a shift from intrusive to extrusive magmatism. This late-stage pulse of decompression melting due to plate thinning may be responsible for the formation of seaward dipping reflector sequences of basalts and sediments, which are ubiquitous at magmatic rifted margins worldwide.
\end{abstract}

(c) 2012 Elsevier B.V. All rights reserved.

\section{Introduction}

Rifting and breakup of the continents can occur by extensional faulting, as well as by ductile stretching and thinning of the continental lithosphere (e.g., McKenzie, 1978). Thinning of the lithosphere results in adiabatic decompression of the underlying asthenosphere, which can result in the production of large volumes of molten rock if the rate and extent of thinning are sufficiently high and if the thermochemical state of the mantle is conducive to it (Bown and White, 1995; Shillington et al., 2009; White and McKenzie, 1989). Intrusion of melt into the lithosphere can also achieve extension, without marked plate thinning (e.g., Mackenzie et al., 2005; Thybo and Nielsen, 2009), but with important implications for the thermal structure and strength of the extending plate (e.g., Bialas et al., 2010; Ebinger, 2005). The breakup of continents therefore occurs by the interplay between

\footnotetext{
* Corresponding author. Tel.: + 442380593786 .

E-mail address: D.Keir@soton.ac.uk (D. Keir).

${ }^{1}$ Now at Department of Earth Science and Engineering, Imperial College, London, London, SW7 2AZ, UK.
}

structural and rheological changes to the lithosphere due to mechanical deformation, heating, and magmatism.

Once a continent has successfully broken apart and seafloor spreading has commenced along a new mid-ocean ridge, the architecture of the once-active continental rift remains frozen beneath the conjugate passive continental margins. Study of passive margin geology, combined with wide-angle seismic imaging of crustal structures and rift stratigraphy provided a primary framework from which to infer the extensional mechanisms and mantle conditions that characterised breakup (e.g., White, 1988; White et al., 2008; Whitmarsh et al., 2001). However, it is difficult to interpret the geological record unambiguously because the tectonic activity that characterised breakup has long-since ceased and the continentocean transition (COT) is sometimes masked by up to several kilometres of late-to-syn rift interbedded basalt flows and sediments (often evaporites). These so-called seaward-dipping reflector sequences reflect back a large proportion of the seismic energy used to image beneath them in controlled-source experiments (Maresh and White, 2005; Mutter, 1985; Mutter et al., 1982; White et al., 2008).

Tectonically active continental rifts and recently developed mid-ocean ridges provide snapshots of rift development. Study of the rift system in Ethiopia is particularly useful because it exposes 
subaerially several stages of magmatically active rift sector development from immature continental rifting in the East African rift to incipient oceanic spreading in the Red Sea and Gulf of Aden (e.g., Barberi et al., 1972; Ebinger, 2005; Hayward and Ebinger, 1996; Makris and Ginzburg, 1987; Mohr, 1967) (Fig. 1). It therefore provides a unique opportunity to develop an understanding of the evolution from mechanical continental rifting to magmatic extension in mid-ocean ridges. Here we synthesise constraints from the southern Red Sea rift in Afar on along-rift variations in crustal structure, style of surface volcanism, shallow magmatic plumbing, surface morphology, and active deformation constrained by seismicity and geodesy. These constraints provide fundamental information on the spatial and temporal evolution of deformation and magma-supply during the late-stages of continental breakup.

\section{Tectonic background}

\subsection{Rifting}

\subsubsection{Rift initiation}

Afar marks a triple junction between the Nubian, Somalian, and Arabian plates, which are diverging due to extension in the Red Sea, Gulf of Aden and East African rifts (e.g., Beyene and Abdelsalam, 2005; Ghebreab, 1998; McKenzie et al., 1970; Mohr, 1970; Tazieff et al., 1972) (Fig. 1). The excellent fit of the southern coast of Arabia into the Horn of Africa was amongst the earliest case studies used to substantiate plate tectonic theory (e.g., McKenzie et al., 1970). Border faults on the SE and SW flanks of the Afar depression mark the abrupt transition from rift valley floor to the $2-3 \mathrm{~km}$ high Ethiopian

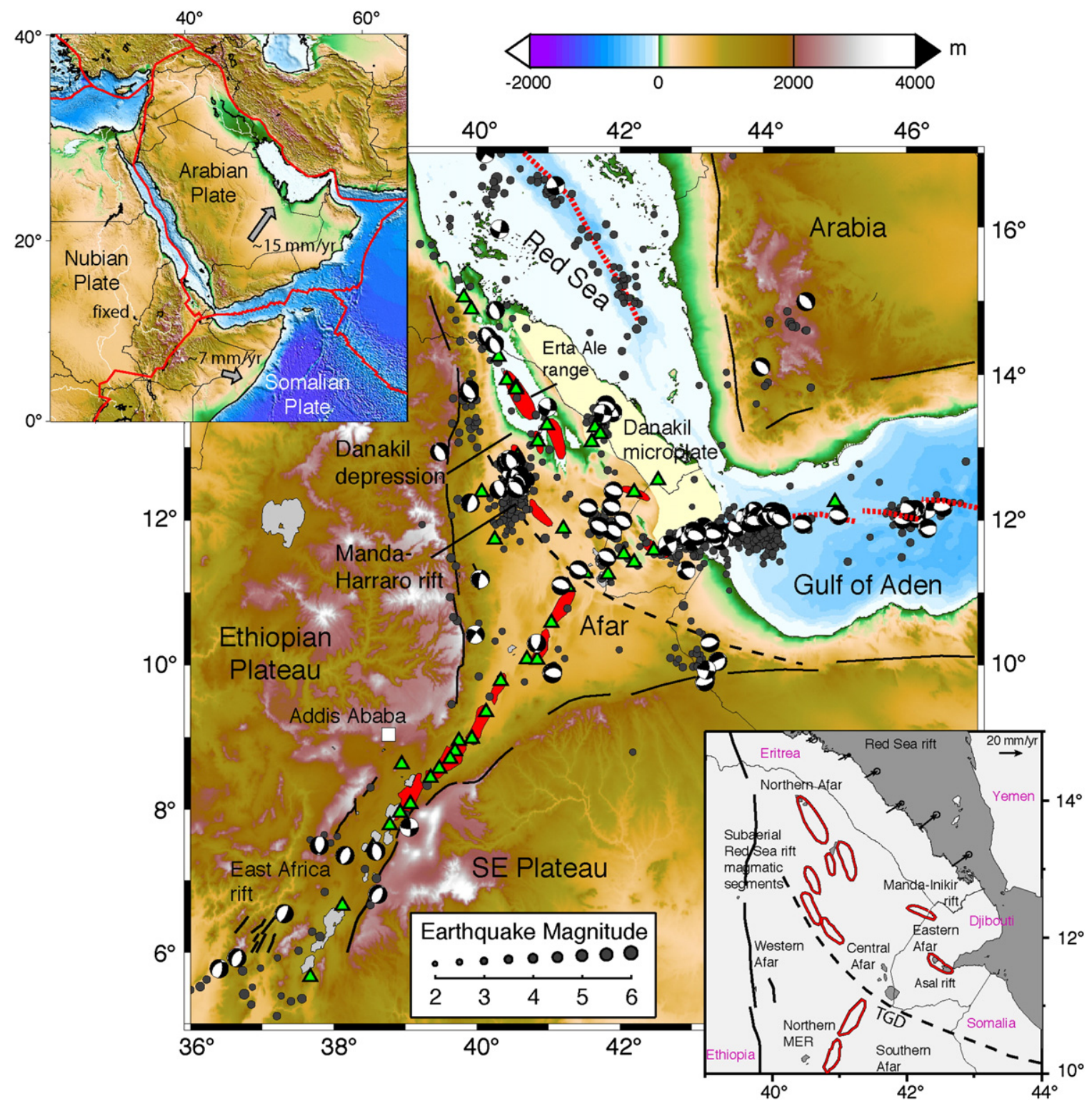

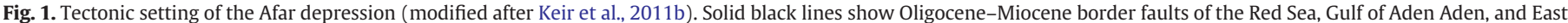

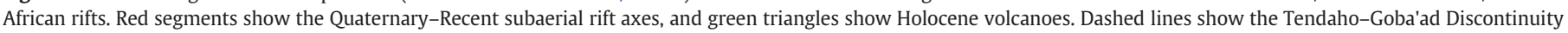

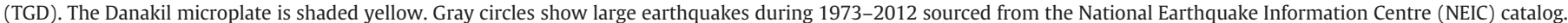

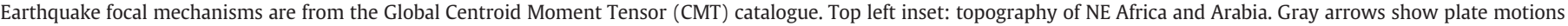

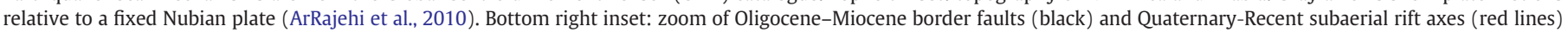
with arrows showing motion of the Danakil microplate (McClusky et al., 2010). 
and Southeastern plateaus. The conjugate rift flanks are located $\sim 350 \mathrm{~km}$ to the northeast defining the southern tip of Arabia in Yemen (e.g., Bosworth et al., 2005) (Fig. 1). Geochronological constraints in Ethiopia suggest rifting began 29-31 Ma on the western Afar margin (e.g., Ayalew et al., 2006; Wolfenden et al., 2005) (Fig. 3), approximately coeval with $\sim 35$ Ma faulting along large portions of the Gulf of Aden (Leroy et al., 2010) (Fig. 2).

The Tendaho-Goba'ad discontinuity (TGD) marks the transition from approximately NE-SW oriented Red Sea/Gulf of Aden AfricanArabian rifting, to approximately E-W oriented Nubian-Somalian extension in the Main Ethiopian Rift (MER) (e.g., Tesfaye et al., 2003) (Figs. 1 and 2). South of the TGD in the East African Rift, MER extension began on large-scale border faults. South of $\sim 7^{\circ} \mathrm{N}$ border fault stratigraphy shows that faulting was well established by $\sim 18 \mathrm{Ma}$ (Bonini et al., 2005; Ebinger et al., 1993; WoldeGabriel et al., 1990). Between $7^{\circ} \mathrm{N}$ and $10^{\circ} \mathrm{N}$, however, syn-rift growth of sedimentary and volcanic sequences, constrained by fission track thermochronology on exposed basement, indicates that rapid growth of border faults may have started somewhat later, between 6 and 11 Ma (Abebe et al., 2010; Bonini et al., 2005; Ukstins et al., 2002; Wolfenden et al., 2004) (Fig. 2). Irrespective of the timing of rift initiation in the MER, the basic observation of NE-NNE striking normal faults of the MER cutting across NW-NNW striking faults in southern Afar suggests extension in the northern MER postdates extension from initial opening of the southern Red Sea and Gulf of Aden (Tesfaye et al., 2003) (Fig. 2).

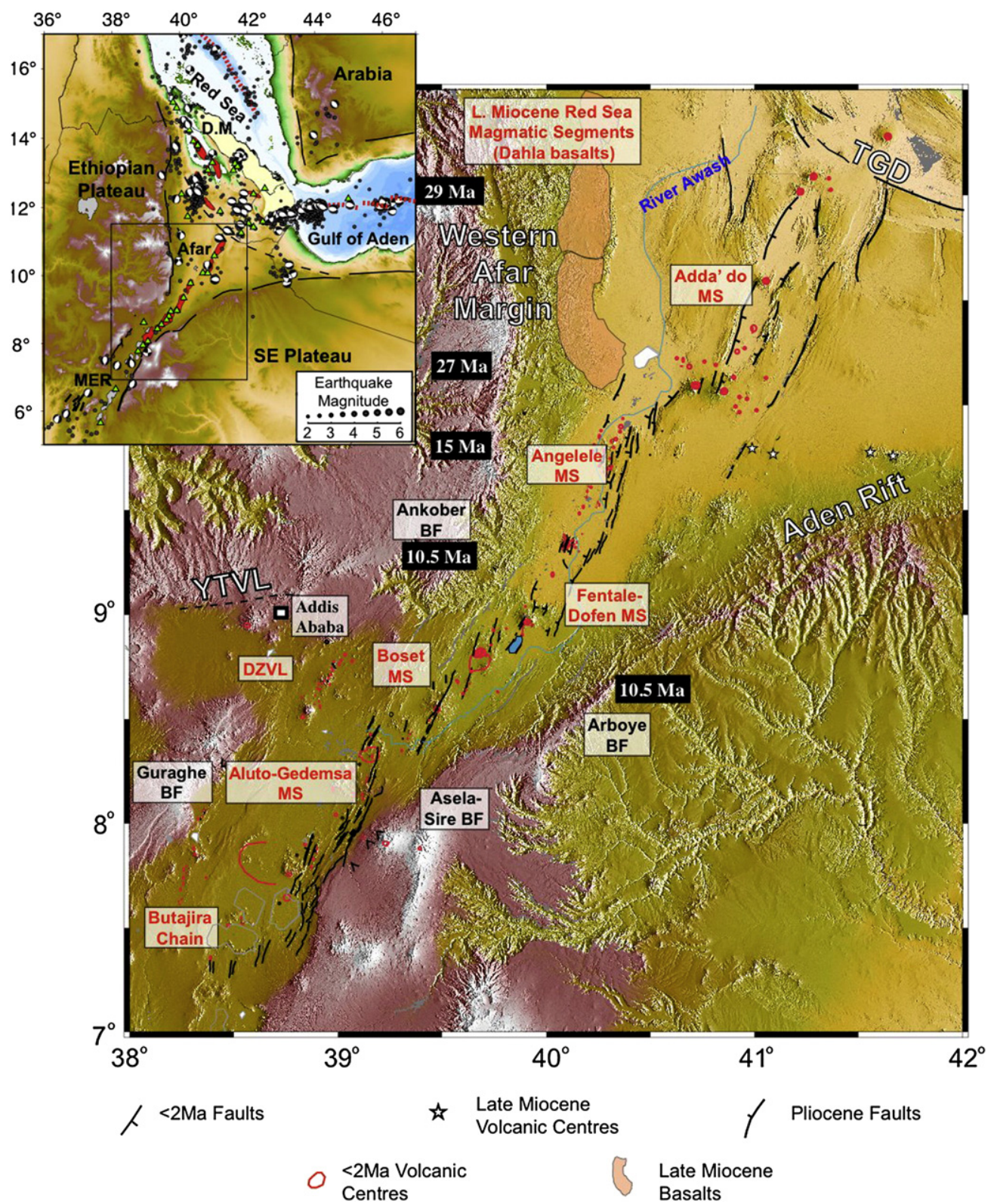

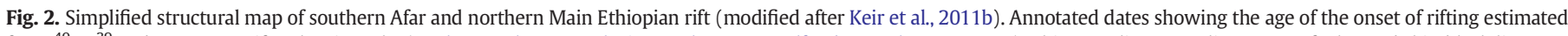

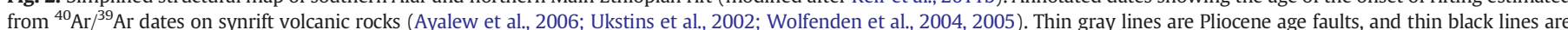

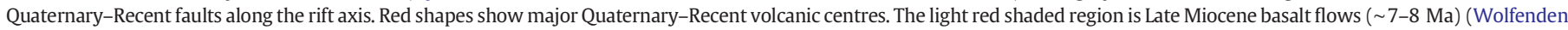

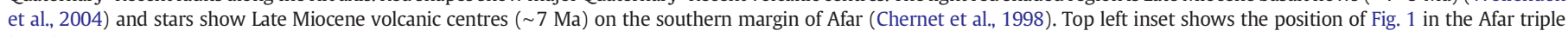
junction. 


\subsubsection{Localisation of strain}

The shorter and simpler history of extension in the MER provides insights into localisation of strain during the Oligocene-Early Miocene evolution of Afar. Since the Quaternary, the principal locus of strain in the MER has shifted from border faults to $~ 30 \mathrm{~km}$-wide, $\sim 60 \mathrm{~km}$-long en-echelon axial magmatic segments (Figs. 1 and 2). These encapsulate active volcanoes (Biggs et al., 2011), aligned monogenetic cones (e.g., Ebinger and Casey, 2001; Mazzarini, 2008; Williams et al., 2004), and small-offset faults striking perpendicular to the direction of extension (Fig. 2) (e.g., Agostini et al., 2011a,b; Corti, 2008, 2009; Hayward and Ebinger, 1996; Keir et al., 2011a). In the MER, gravity and seismic imaging show that magmatic segments are underlain by dense, high seismic velocity material, interpreted as cooled gabbroic intrusions (e.g., Beutel et al., 2010; Cornwell et al., 2006; Keranen et al., 2004; Mackenzie et al., 2005; Maguire et al., 2006). Since the voluminous intrusions into the mid-upper crust appear largely restricted to beneath the Quaternary-Recent magmatic segments, it is likely that magma intrusion has only dominated extension during the past $2 \mathrm{Ma}$ (Daly et al., 2008; Keranen et al., 2004).

A similar transition from mechanical to magmatic extension to that observed in the MER occurred during Miocene times in the Red Sea rift system in Afar. The synrift volcanic geology of the western Afar margin shows that during the period 25-7 Ma, extension and volcanism in the southern Red Sea rift migrated 40-50 km westward of the main border fault; the morphology and spatial extent of lava flows suggest that intrusion and volcanism localised to narrow magmatic segments akin to those that are currently active in the MER (Ayalew et al., 2006; Wolfenden et al., 2005) (Fig. 2). Over time, the locus of extension and magmatism has migrated eastwards overall in the Red Sea rift system (Ayalew et al., 2006; Wolfenden et al., 2005), leaving a suite of near surface volcanic rocks that young towards the Quaternary-Recent axial magmatic segments where faulting and magmatism is now localised (e.g., Barberi and Varet, 1977; Manighetti et al., 2001) (Fig. 1).

\subsubsection{Current plate motions}

Kinematic models constrained by GPS data suggest $6-8 \mathrm{~mm} / \mathrm{yr}$ of $\sim \mathrm{N} 100^{\circ} \mathrm{E}$ directed opening in the central and northern MER (Fig. 1) (e.g., Fernandes et al., 2004; Jestin et al., 1994; Stamps et al., 2008). Similar models suggest $\sim 15 \mathrm{~mm} / \mathrm{yr}$ of $\sim \mathrm{N} 35^{\circ} \mathrm{E}$ directed opening across the western Gulf of Aden rift (e.g., Jestin et al., 1994). Current opening across the kinematically complex southern Red Sea rift is well constrained with a relatively high density of GPS measurements (e.g., ArRajehi et al., 2010; McClusky et al., 2010). These data show that south of $\sim 16^{\circ} \mathrm{N}$, the rift bifurcates into two branches: the main Red Sea and the subaerial Red Sea rift in Afar (Danakil depression) (Figs. 1 and 3). Partitioning of extension between rift branches varies along strike. North of $\sim 16^{\circ}$, all the extension is accommodated in the main Red Sea rift, spreading at $\sim 15 \mathrm{~mm} / \mathrm{yr}$. Moving south of $16^{\circ} \mathrm{N}$, the extension is progressively accommodated in the Afar depression reaching $\sim 20 \mathrm{~mm} / \mathrm{yr}$ at $\sim 13^{\circ} \mathrm{N}$ (McClusky et al., 2010; Vigny et al., 2006) (Figs. 1 and 3). When viewed in light of spreading rates observed in the ocean basins, the rates of extension observed in Afar would place it in the ultra-slow to slow category typically resulting in low-moderate volumes of magma production (e.g., Dick et al. 2003; Phipps-Morgan and Chen, 1993). In this paper we discuss the importance of both elevated mantle temperature combined with variable rates of thinning the continental lithosphere as being responsible for large volumes of magmatism during extension in Ethiopia.

\subsection{The Ethiopian mantle}

\subsubsection{Physical state of the Ethiopian mantle: evidence from the geological record}

The $\sim 2 \mathrm{~km}$ thick sequences of flood basalts and rhyolites that erupted onto the Ethiopian plateau (e.g., Baker et al., 1996; Hofmann et al., 1997) prior to or concomitant with the 29-31 Ma onset of extension in the Red Sea and Gulf of Aden rift systems (e.g., Wolfenden et al., 2004), have frequently been cited as evidence for one or more traditional mantle plumes beneath the region. The location and number of plumes or upper mantle convective cells are debated, however (e.g., Beccaluva et al., 2009; Burke, 1996; Courtillot et al., 1999; Ebinger and Sleep, 1998; Furman et al., 2006; George et al., 1998; Kieffer et al., 2004; Rogers, 2006; Rogers et al., 2000; Rooney et al., 2012a,b; Schilling et al., 1992). Ebinger and Sleep (1998), for example, suggested that one large plume spread beneath the African Plate near Turkana at $45 \mathrm{Ma}$, with melt production minimal until lithospheric thinning commenced in the Red Sea and Gulf of Aden. Zones of thinned lithosphere then channeled buoyant asthenosphere up to $\sim 1000 \mathrm{~km}$ laterally to the evolving African-Arabian rift system in the Horn of Africa. George et al. (1998) and Rogers et al. (2000), on the other hand, cited petrological differences between Afar and Kenyan lavas as evidence that two Cenozoic plumes may have existed, one rising and dispersing beneath southern Ethiopia $45 \mathrm{Ma}$ and the other rising beneath the Afar depression.

Most recently, Rooney et al. (2012a) present mantle Tp estimates for 53 primitive magmas from throughout Ethiopia. They showed that mantle potential temperature anomalies currently peak in $\mathrm{Dji}-$ bouti, at $140{ }^{\circ} \mathrm{C}$ above ambient mantle. Slightly hotter $\left(+170{ }^{\circ} \mathrm{C}\right)$ conditions characterised the $\sim 30 \mathrm{Ma}$ formation of the Ethiopian traps.

\subsubsection{Evidence from broadband seismology}

In recent years, major geoscientific experiments in Ethiopia such as the Ethiopia-Kenya Broadband Seismic Experiment (EKBSE; e.g., Benoit et al., 2006) and the Ethiopia Afar Geoscientific Lithospheric Experiment (EAGLE; e.g., Bastow et al., 2011) have facilitated increasingly high resolution imaging of the Ethiopian mantle. Seismic tomographic studies on the global-to-regional scale, however, have revealed a broad ( $500 \mathrm{~km}$-wide) $\sim 3 \%$ slow shear wave-speed anomaly that originates at the core-mantle boundary beneath southern Africa and extends toward the base of the lithosphere somewhere beneath Ethiopia (e.g., Grand, 2002; Li et al., 2008; Ritsema and Allen, 2003; Ritsema et al., 2010; Simmons et al., 2007): the African superplume (Figs. 4 and 5). These global-scale models have subsequently been used in geodynamic models that successfully predict the amplitude and wavelength of plateau uplift in the region (e.g., Daradich et al., 2003; Forte et al., 2010; Moucha and Forte, 2011), consistent with evidence from $\mathrm{U}-\mathrm{Th} / \mathrm{He}$ thermochronometry data that indicate broad-scale plateau uplift began in the interval 20-30 Ma (Pik et al., 2003).

The seismic discontinuities nominally found at depths of $410 \mathrm{~km}$ and $660 \mathrm{~km}$ due to the olivine-to-wadsleyite and ringwooditeto-perovskite + magnesiowustite phase transitions in the olivine system will vary in depth dependent on temperature (e.g., Bina and Wood, 1987; Helffrich, 2000). In the case of Ethiopia, transition zone thickness, determined by receiver function analysis, shows evidence for thinning compared to the global mean; Cornwell et al. (2011) cited this as evidence for high temperatures at transition zone depths, and thus connectivity between shallow low velocities imaged tomographically in Ethiopia (e.g., Bastow et al., 2008; Benoit et al., 2006; Debayle et al., 2001; Hansen et al., 2012; Pasyanos and Nyblade, 2007) and the superplume in the lower mantle beneath.

Uppermost mantle Pn velocities from wide-angle seismic (e.g., Berckhemer et al., 1975; Makris and Ginzburg, 1987) and local earthquake data (Stork et al., in review) are as low as $7.2 \mathrm{~km} / \mathrm{s}$ beneath Afar - markedly low compared to the global mean and compared to extensional settings with similar rates of opening (Fig. 6). These low Pn velocities are consistent with the presence of 3\% partial melt in the upper mantle (Stork et al., in review). 


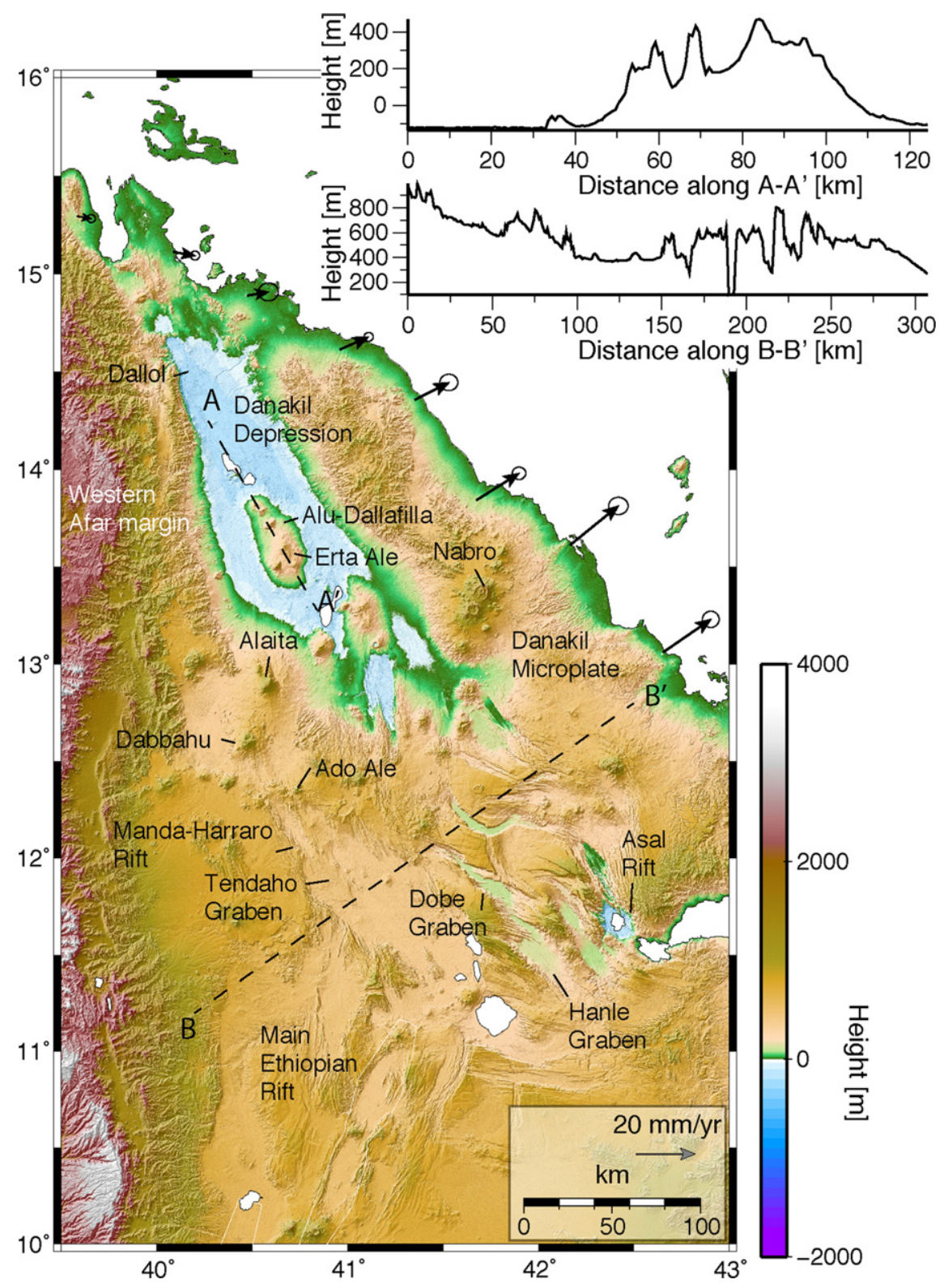

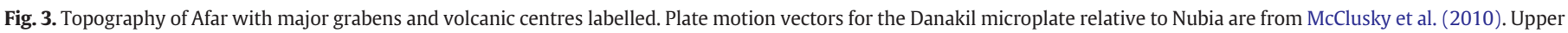
right panel shows samples of topography on profiles $A-\mathrm{A}^{\prime}$ in the Danakil depression and B-B' across central Afar.

Measurements of seismic anisotropy in Ethiopia provide constraints on lithospheric deformation processes and flow in the underlying asthenosphere. In the MER, high-density splitting analysis of SKS phases in tandem with surface-wave studies is sensitive to a $\sim 20^{\circ}$ change in orientation of strain fabrics from $\mathrm{N} 30-40^{\circ} \mathrm{E}$ at the rift margins to $\mathrm{N} 10^{\circ} \mathrm{E}$ along the rift axis. This change is interpreted as caused by the localisation of magma intrusion through the whole lithosphere toward the rift axis 2 Ma (Bastow et al., 2010; Kendall et al., 2005, 2006). NE of the TGD in the Red Sea and Gulf of Aden rifts in Afar, Gao et al. (2010) use the backazimuthal variations in SKS splitting to show rift parallel anisotropy throughout the lithosphere. They interpret this as strain related structures such as magmatic intrusions, a similar interpretation as by Kendall et al. (2005, 2006) and Bastow et al. (2010) in the MER. Below the lithosphere, anisotropic fast directions parallel the N30$40^{\circ} \mathrm{E}$ trend of the African Superplume and are most sensibly interpreted as related to alignment of olivine in the asthenosphere induced by subhorizontal flow (e.g., Bastow et al., 2010; Gao et al., 2010; Kendall et al., 2006; Obrebski et al., 2010).
2.2.3. Implications for the thermochemical state of the Ethiopian mantle

The consensus emerging from recent studies in Ethiopia is that it is underlain by a broad low velocity anomaly, not a traditional narrow mantle plume (e.g., Bastow et al., 2008; Benoit et al., 2006; Cornwell et al., 2011; Hansen et al., 2012; Ritsema et al., 2010) (Fig. 5). More difficult to constrain, however, is the extent to which low velocities are due to elevated mantle potential temperature, shallow melt due to extension-derived decompression melt, or an anomalously fertile mantle. The petrological constraints on Tp presented by Rooney et al. (2012a) show that anomalies peaked at $+170{ }^{\circ} \mathrm{C}$ during the 30 Ma flood basalt event, and since have fallen slightly to $+140{ }^{\circ} \mathrm{C}$. These temperatures plot towards the low end of the global temperature range of large igneous provinces, despite the fact that mantle wave-speeds beneath Ethiopia are likely amongst the slowest on Earth (e.g., Bastow and Keir, 2011) (Fig. 4). Mantle seismic wavespeed anomalies beneath Ethiopia cannot, therefore, be attributed entirely to the effects of elevated temperature. Rooney et al. (2012a) thus proposed that $\mathrm{CO}_{2}$ assisted melt production likely contributes 

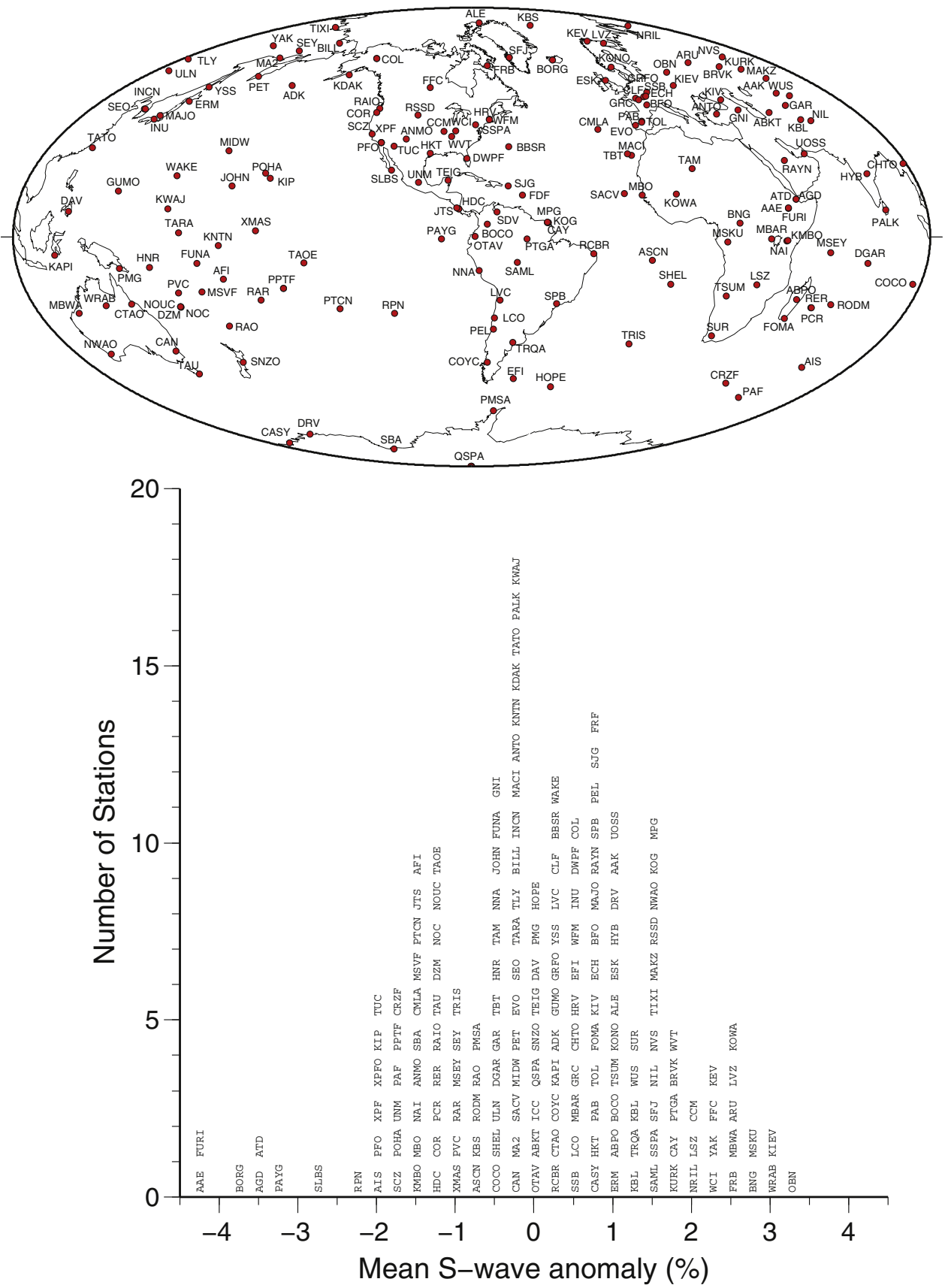

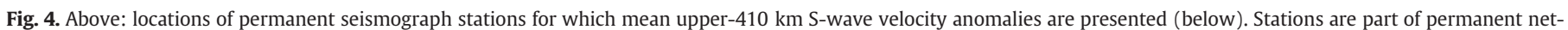

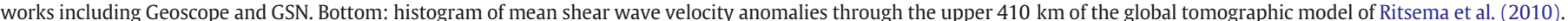

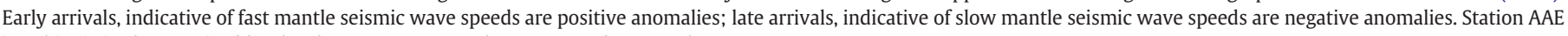
in Ethiopia is characterised by the slowest upper mantle wave speeds on Earth.

Modified after Bastow (2012).

to the low seismic wave-speeds of the region at depth, with decompression melting due to rifting a major contributing factor in the asthenosphere. The observed $\sim 140{ }^{\circ} \mathrm{C}$ thermal anomaly is, however, in the presence of plate thinning, very much of the order capable of producing a large igneous province $\left(100-200{ }^{\circ} \mathrm{C}\right.$ : White and McKenzie, 1989), as was observed in Ethiopia 30 Ma.

\section{Along-rift variations in the southern Red Sea rift of Afar}

The geology of the southern Red Sea margin suggests that by 20-25 Ma, strain had shifted to narrow rift axial zones characterised by basaltic fissural eruptions and faults with metre-scale offsets
(Wolfenden et al., 2005) (Fig. 2). The progression and relative timing of rift initiation on border faults to a narrow zone of magma intrusion are remarkably similar to that observed in the younger MER. This points towards a generic evolutionary model in which faulting and plate stretching are replaced as the primary locus of extension by magma intrusion relatively early (prior to an extension factor of 2 ) during rift evolution. Here we synthesise Pliocene-Recent ( $<5.2 \mathrm{Ma}$ ) developments in structural morphology and deformation of the southern Red Sea rift in Afar and discuss the relationship between plate stretching and resultant thinning, production of magma in the asthenosphere, and magma intrusion. In particular, we draw attention to consistent indicators of a dramatic change in style of rifting from the Manda-Harraro rift (MHR) 


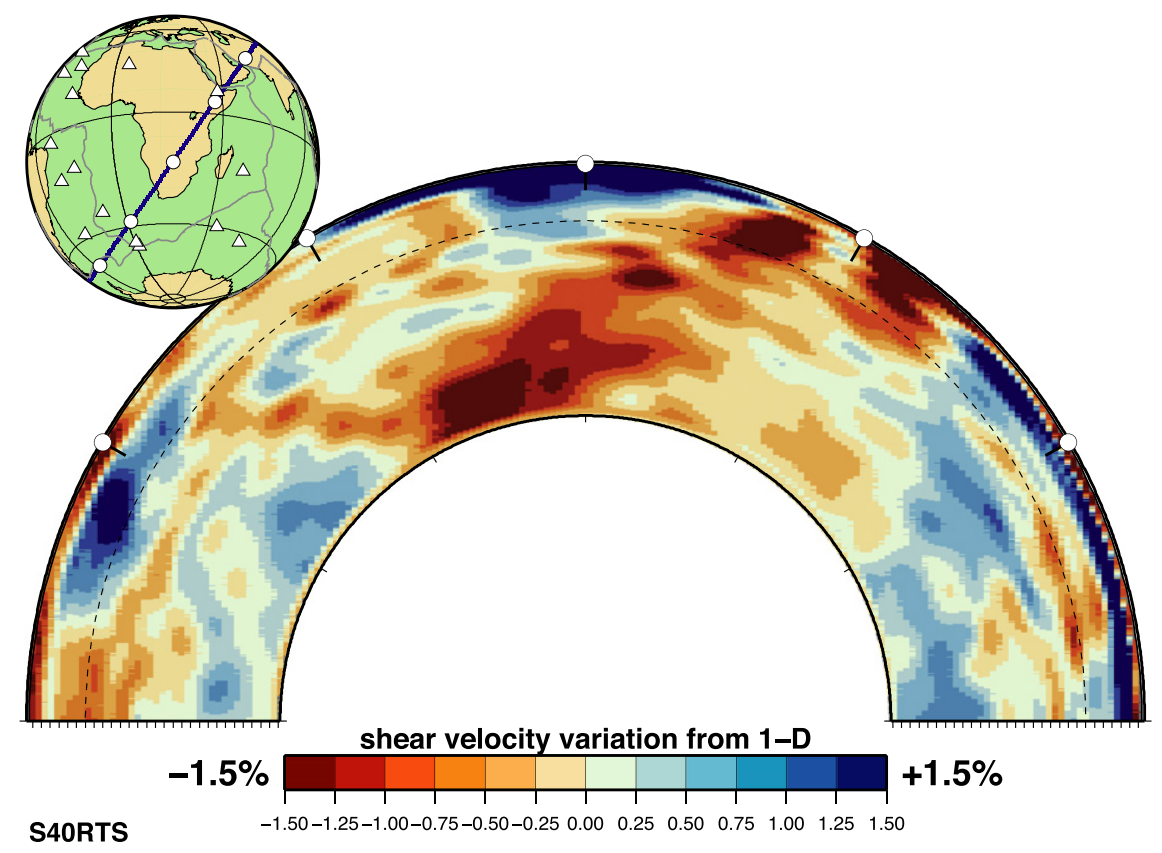

Fig. 5. Whole-mantle cross-sections centred on east Africa for the global S-wave tomographic model S40RTS. Shear-velocity perturbations are between $-1.5 \%$ and $+1.5 \%$. Modified after Ritsema et al. (2010).

and Tendaho Graben (TG) into the Danakil depression of northernmost Afar (Figs. 1 and 3).

\subsection{Crustal structure}

The structure and composition of the crust beneath Afar have been the subject of much debate during the last $~ 35$ years (e.g., Berckhemer et al., 1975; Hammond et al., 2011; Makris and Ginzburg, 1987; Mohr, 1970, 1989). Discussion has often focussed on whether the crust is completely new oceanic crust, or whether it is stretched and thinned continental crust, heavily intruded by

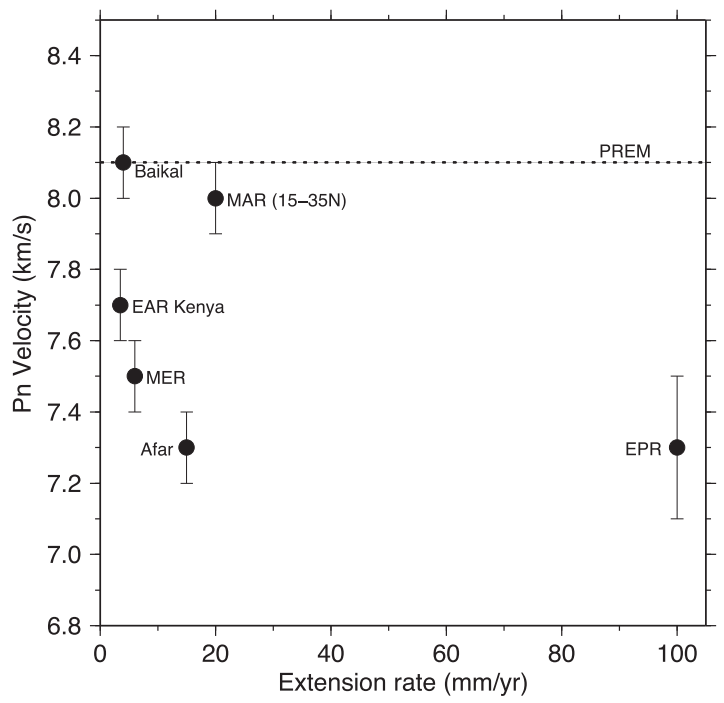

Fig. 6. Variation in Pn velocity at major continental rifts and ridges worldwide compared to PREM (Dziewonski and Anderson, 1981). Regions of extension above mantle thermal anomalies (e.g., East Africa and Ethiopia: Prodehl et al., 1997) have lower Pn velocities than settings at similar extension rates, but which lie above "normal" mantle (e.g., Baikal: Thybo and Nielsen, 2009; Mid Atlantic Ridge: Dziak et al., 2004). Lower velocities are observed at the East Pacific Rise (EPR) because it is a region of high melt production due to fast spreading (e.g., Dunn and Toomey, 1997). magma (transitional crust). Constraints on crustal structure primarily come from wide-angle seismic studies (Berckhemer et al., 1975; Maguire et al., 2006; Makris and Ginzburg, 1987; Prodehl et al., 1997), teleseismic receiver function studies (Ayele et al., 2004; Dugda et al., 2005; Hammond et al., 2011; Stuart et al., 2006), and from gravity analysis (Redfield et al., 2003; Tessema and Antoine, 2004; Tiberi et al., 2005). Results achieved using these different methods are broadly consistent (e.g., Fishwick and Bastow, 2011).

The crust in Ethiopia is thickest beneath the Ethiopian Plateau (40-45 km); it is $\sim 35 \mathrm{~km}$ thick beneath the Southeastern Plateau. The crust thins abruptly to 15-30 km into Afar (Fig. 7) (e.g., Maguire et al., 2006; Stuart et al., 2006). The crust throughout Ethiopia has a consistent, unbroken layering with lower crust of $\mathrm{Vp}=6.7-7.0 \mathrm{~km} / \mathrm{s}$, an upper crust of $\mathrm{Vp}=6.0-6.3 \mathrm{~km} / \mathrm{s}$, and cover rocks of lava flows and sediments of $\mathrm{Vp}=2.2-4.5 \mathrm{~km} / \mathrm{s}$ (Makris and Ginzburg, 1987; Prodehl and Mechie, 1991). The cover rocks are generally thickest where the crust is thinnest suggesting a strong link between crustal thinning, rift valley subsidence and resultant accumulation of basin infill. The seismic velocity structure of Afar crust contrasts that observed in the submarine ocean ridges in the Red Sea and Gulf of Aden where the crust is less than $\sim 10 \mathrm{~km}$-thick and displays a different internal architecture seismically (Prodehl and Mechie, 1991). The crust beneath Afar is considered to be variably stretched and intruded continental crust, and not yet oceanic in nature (Makris and Ginzburg, 1987).

In central Afar, the crust is $20-25 \mathrm{~km}$ thick beneath the current locus of volcanism and strain in the MHR and TG (Fig. 7). The crust is of similar thickness in a $\sim 40 \mathrm{~km}$-wide strip near the western Afar margin (Hammond et al., 2011), where extension is inferred to have localised in Miocene times during the development of the southern Red Sea rift (Dahla basalts) (Wolfenden et al., 2005 (Fig. 2). The regions of crustal thinning in the present and past loci of strain are separated by $30 \mathrm{~km}$ thick crust, as it also is beneath the Danakil microplate (Hammond et al., 2011; Makris and Ginzburg, 1987). The spatial variation in crustal thickness across central Afar is broadly consistent with that expected from a progressive northeast migration of strain in the vicinity of a northeastward migrating triple junction, but with strain re-localisation occurring in abrupt rift jumps rather than as a continuous migration (Hammond et al., 2011; Wolfenden et al., 2005). 
The most dramatic spatial variation in crustal structure within Afar occurs north of $\sim 13^{\circ} \mathrm{N}$, where the crust thins from 20 to $25 \mathrm{~km}$ in the MHR and adjacent regions to $\sim 15 \mathrm{~km}$ beneath the Danakil depression surrounding the Erta Ale volcanic range (Hammond et al., 2011; Makris and Ginzburg, 1987) (Fig. 7). The change in crustal thickness along-rift from south to north is primarily accounted for by markedly thinned lower crust, though the upper-crust is also appreciably thinner (Makris and Ginzburg, 1987). The Danakil basin is also characterised by the thickest sedimentary basins in Afar: $\sim 5 \mathrm{~km}$ as opposed to $2-3 \mathrm{~km}$ elsewhere. These spatial variations in crustal thickness in Ethiopia correlate well with variations in effective elastic plate thickness $(\mathrm{Te})$, with strongest plate $(\mathrm{Te} \approx 60 \mathrm{~km})$ beneath the plateaus, and weakest plate $(\mathrm{Te} \approx 6 \mathrm{~km})$ beneath the Danakil depression (Ebinger and Hayward, 1996; Pérez-Gussinyé et al., 2009). Both crustal thickness and plate strength also correlate with variations in seismogenic layer thickness, which is $25-30 \mathrm{~km}$ beneath the Ethiopian plateau (Keir et al., 2009a) and $~ 5 \mathrm{~km}$ beneath the Danakil depression (Craig et al., 2011).

In addition to crustal thickness, receiver function studies constrain bulk crustal $\mathrm{Vp} / \mathrm{Vs}$ ratios. In general, the plateaus have $\mathrm{Vp} / \mathrm{Vs}$ of 1.7-1.9, whereas localised regions of thicker ( $30 \mathrm{~km}$-thick) crust within Afar have Vp/Vs of 1.8-1.9 (Dugda et al., 2005; Hammond et al., 2011). Vp/Vs $\leq 1.85$ can be explained compositionally, but observations of $\mathrm{Vp} / \mathrm{Vs}>1.85$ strongly suggest present-day melt. Near the active Quaternary-Recent magmatic segment and beneath the Miocene Dahla basalts, where crustal thickness is $<30 \mathrm{~km}, \mathrm{Vp} / \mathrm{Vs}$ is high at 1.9-2.1 - also strong evidence for partial melt in the crust (Dugda et al., 2005; Hammond et al., 2011).

Constraints on crustal structure in Afar also come from gravity and magnetic studies, particularly from a $50 \mathrm{~km}$-long, 1 m station density profile across the TG (Bridges et al., 2012). Here the magnetic data show near symmetrical anomalies across the centre of the rift, with the scale, shape and magnitude of the anomalies similar to that observed in nearby seafloor spreading centres in the Gulf of Aden. These data, together with the Bouguer gravity field are consistent with symmetrical sheeted mafic dike complex intruded into the upper $\sim 10 \mathrm{~km}$ of the crust, and capped by $2-3 \mathrm{~km}$-thick basin fill of fissural basalts and sediments (Bridges et al., 2012).

\subsection{Rift morphology, stratigraphy, and volcanic geology}

The constraints on crustal thickness in Afar show that the most significant variation along the subaerial Red Sea rift system occurs across $\sim 13^{\circ} \mathrm{N}$, where the magmatic segments step to the right northward into the Danakil depression (Fig. 7). The change in crustal thickness also marks a significant along-rift change in the morphology, character of basin-fill stratigraphy, and style of magmatism, which in turn provides clues to extensional processes during continental breakup.

\subsubsection{Manda-Harraro rift and Tendaho graben}

At the southernmost extent of the Red Sea rift, the MHR and TG define a series of NNW-SSE striking, 30-60 km-wide, $80 \mathrm{~km}$-long fault bound basins that include volcanoes that feed mainly rhyolitic and basaltic lava flows (e.g., Acocella et al., 2008; Manighetti et al., 2001) (Figs. 3 and 8). The basins are bound by flanks 200-300 m higher than the lowest elevation of the basin floor, which is 300-500 $\mathrm{m}$ above sea-level (Figs. 3 and 8). A clear single border fault is generally lacking, with faulting instead characterised by numerous closely spaced relatively small-offset faults distributed across the rift (e.g., Acocella, 2010; Manighetti et al., 2001; Rowland et al., 2007). The basins are filled with $2-3 \mathrm{~km}$ of lacustrine and fluvial deposits as well as by Quaternary-Recent volcanic rocks (Acocella et al., 2008), the distribution and age of which constrain basin evolution. These data broadly show that faulting and volcanism have progressively localised through the Quaternary to a $\sim 10 \mathrm{~km}$-wide central axis where the youngest ( $0-0.2 \mathrm{Ma}$ old) fissural basalts crop out (Acocella, 2010; Acocella et al., 2008; Lahitte et al., 2003a,b).

On a regional scale, the $\sim$ NNW trending MHR and TG are $50-150 \mathrm{~km}$ from the $\sim 2 \mathrm{~km}$ elevation margin of western Afar, and $\sim 200 \mathrm{~km}$ from the $\sim 500$ m elevation Danakil microplate on the eastern margin of Afar (Figs. 3 and 8). The MHR and TG are therefore relatively narrow basins set within a $250-450 \mathrm{~km}$ wide Afar depression that has experienced deformation during the last 35 Ma from separation of all plates forming the Afar triple junction. On the rift valley floor west of the MHR and TG, N-NW trending fault networks and volcanic systems related to Miocene extension in the southern Red Sea rift have since been overprinted by NNE-NE striking features of the East African rift (Tesfaye et al., 2003; Wolfenden et al., 2004) (Fig. 2). Conversely, to the east of the MHR and TG, the Afar depression is characterised by a series of relatively narrow, non-volcanic grabens, such as the Dobi, Hanle and Guma grabens, that transfer strain from the southernmost Red Sea rift to the westernmost Gulf of Aden in the Asal Ghoubet and Manda-Inikir rifts (Manighetti et al., 1997; Souriot and Brun, 1992; Tapponnier et al., 1990; Tesfaye, 2005; Tesfaye et al., 2008) (Fig. 8). The position of the MHR and TG, which is close to central Afar, requires the localisation of strain in these rift sectors to be heavily influenced by the progressive NE migration of the Afar triple junction, an inference supported by geological and geophysical indicators of NE migration of extension in the southernmost Red Sea (e.g., Audin et al., 2004; Tesfaye et al., 2003; Wolfenden et al., 2005). Migration of the locus of strain near central Afar is exceptionally important when interpreting the evolution of deformation, since crustal deformation mechanisms such as magma intrusion and faulting are unlikely to be localised beneath any single graben system for longer than a few million years. Over geological time, this creates a wide swath of faulted and intruded continental crust and a temporally protracted continent-ocean transition.

\subsubsection{Danakil depression}

The morphology of the Danakil depression of northern Afar differs markedly to the MHR and TG. Here, the $\sim 200 \mathrm{~km}$-long basin is relatively narrow (50-150 km-wide) and bound directly to the west by a prominent border fault system forming $\sim 3 \mathrm{~km}$ of relief at the western Afar margin (Figs. 3 and 8 ). To the east it is bound by a less prominent series of faults forming a 500-1000 m elevation flank of the Danakil microplate. Despite being on-land, the basin floor is generally 50-100 m below sea-level with near surface geology dominated by the full suite of Pliocene-Recent marine evaporite deposits (e.g., calcite, gypsum, halite, and sylvite), formed from complete evaporation of seawater during repeated marine incursions as recently as $\sim 30 \mathrm{ka}$ (e.g., Barberi and Varet, 1970; Bonatti et al., 1971; Hutchinson and Engels, 1972; Talbot, 2008). The basin also contains non-marine evaporites from on-going evaporation of seasonal terminal saline lakes and the geothermal pools (Talbot, 2008). Plate reconstructions suggest that the Danakil basin has been the locus of strain in northern Afar since at least $11 \mathrm{Ma}$, with the increased distance from complex triple junction tectonics influencing central Afar resulting in a longer history of localised extension (Eagles et al., 2004).

The Danakil depression is bisected by a linear, NNW-striking, $10-20 \mathrm{~km}$ wide axial volcanic range (Erta Ale range) which is the locus of on-going volcanism and magmatism (Barberi and Varet, 1970; Pagli et al., 2012) (Figs. 3 and 8). Unlike elsewhere in Afar, the axial range does not form a heavily faulted graben, but instead forms an axial high composed of at least 4 volcanic centres (e.g. Tat Ale, Erta Ale, Dallafilla, Gada Ale) that reach up to $\sim 500 \mathrm{~m}$ above sea-level (e.g., Barberi and Varet, 1970; Pagli et al., 2012; Thurmond et al., 2006) (Fig. 3). The volcanic rocks are heavily dominated by Quaternary-Recent a'a and pahoehoe basalt flows (Thurmond et al., 2006), and these cover an order of magnitude more surface area than similar age basalts elsewhere in Afar (Bastow and Keir, 2011) (Fig. 7). Basalt flows are fed from a combination of $\sim$ NNW-striking 
A

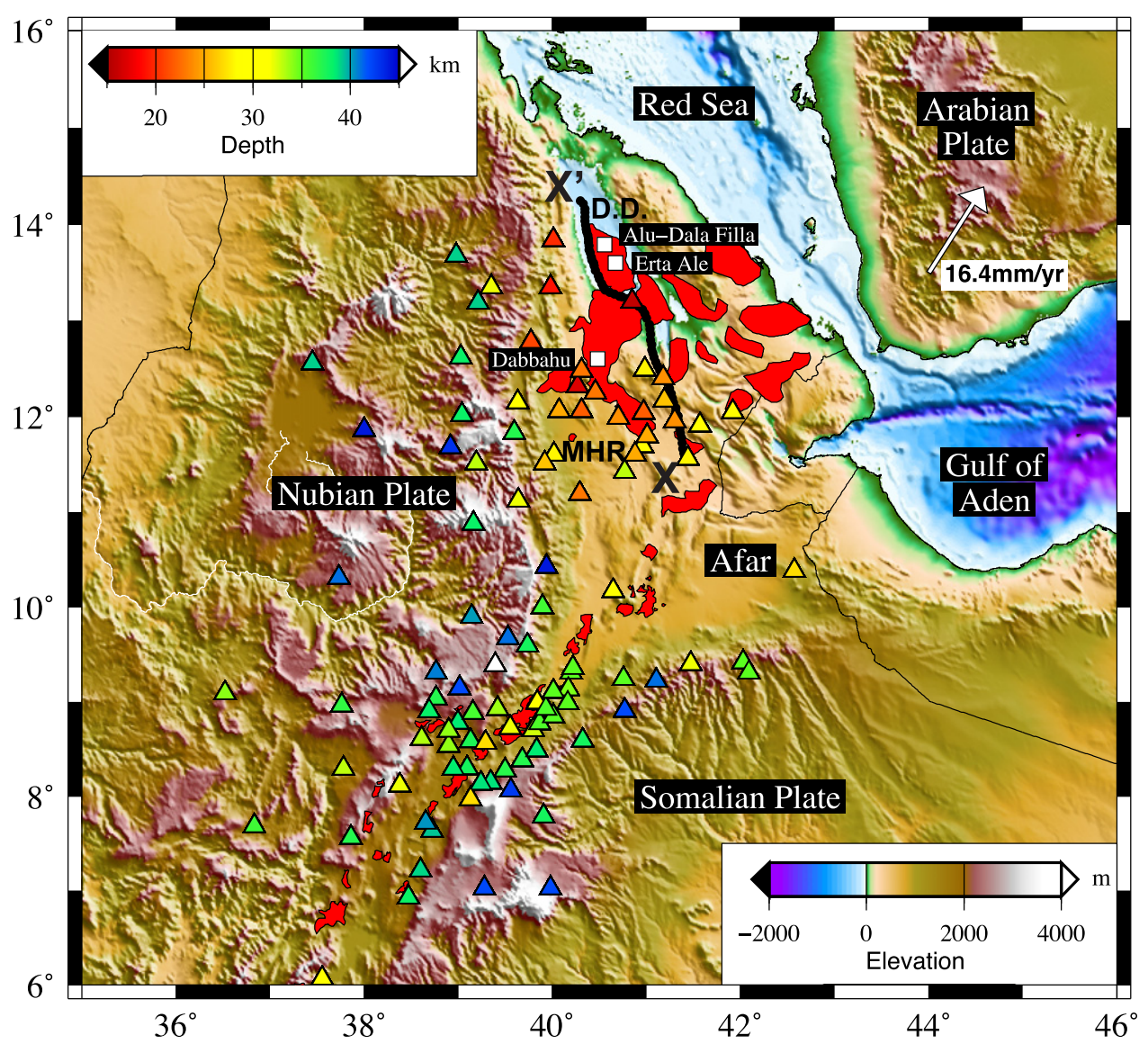

$\mathrm{B}$

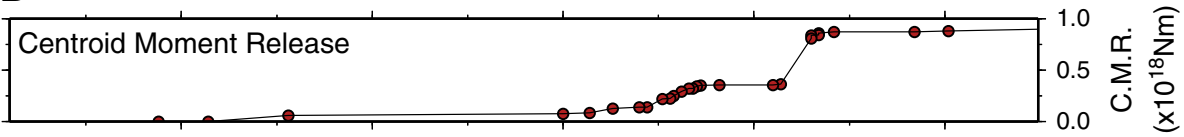

Decompression melting and

SDR formation

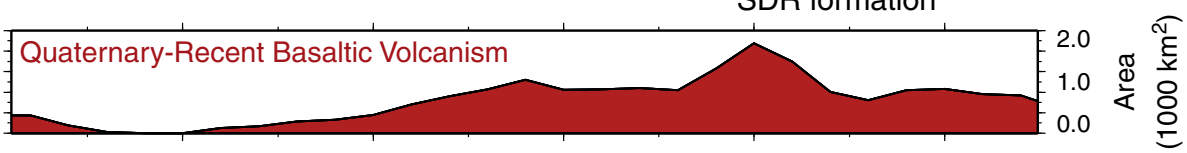

Extension by

Stretching of heavily intruded

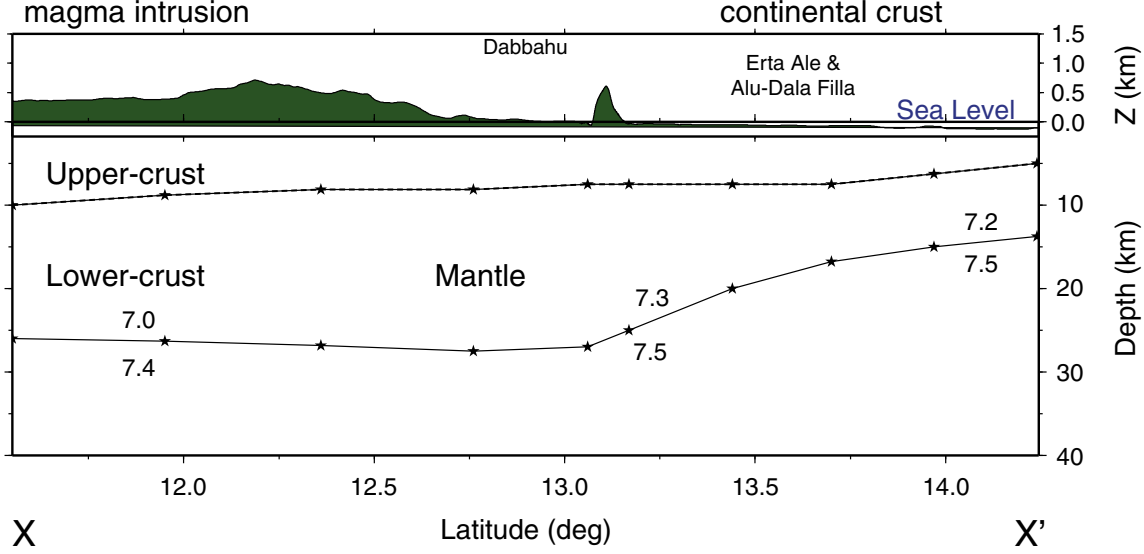




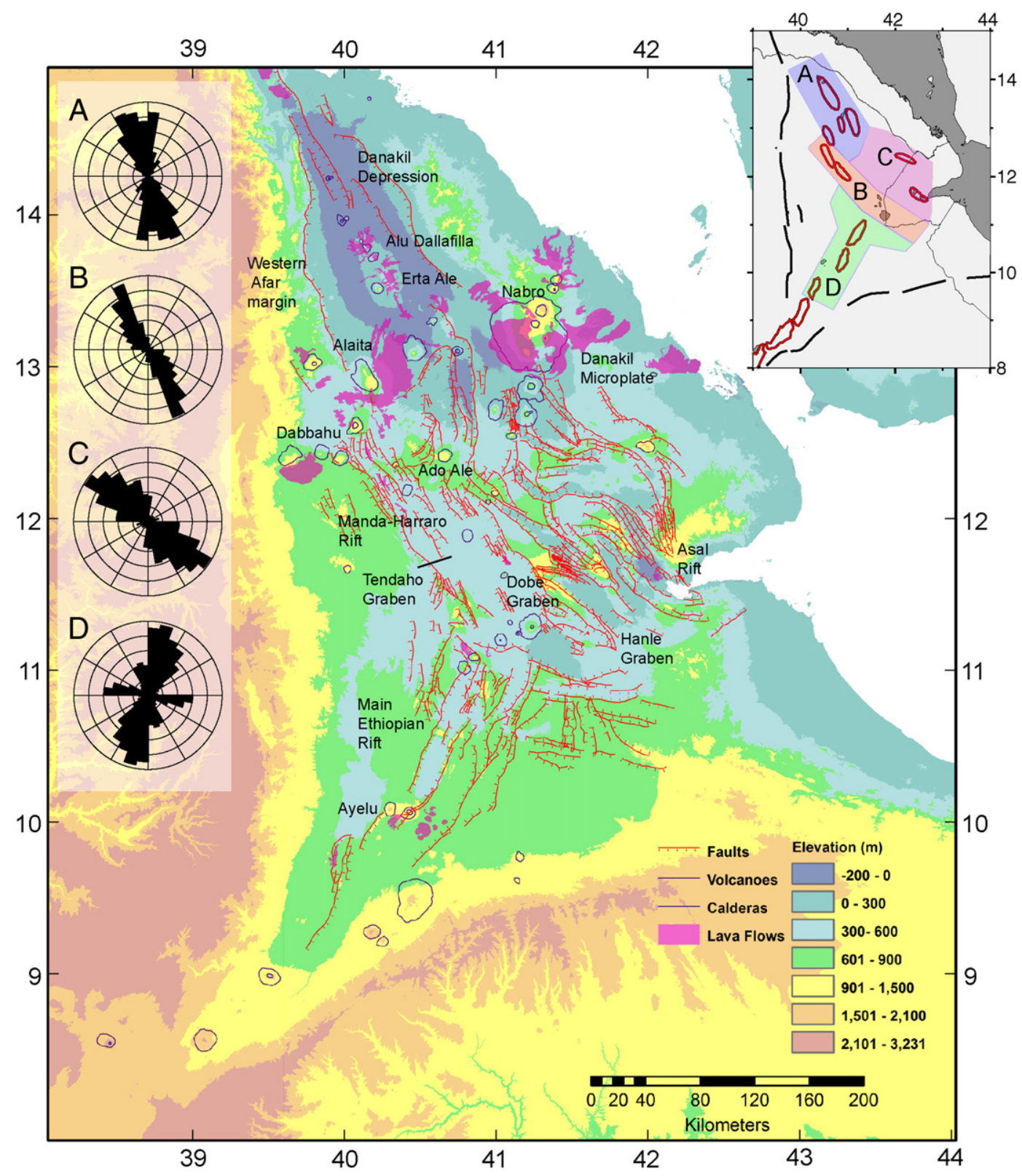

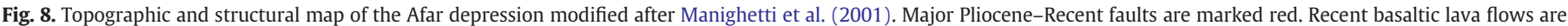

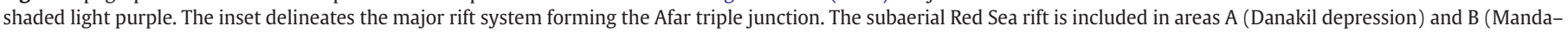
Harraro rift and Tendaha graben). The subaerial Aden rift is included in region C, and the northern Main Ethiopian rift is area D.

fissures and from edifices such as the nested calderas hosting Erta Ale lava lake (e.g., Acocella, 2006; Oppenheimer and Francis, 1998). The lava flows covering the range are mostly erupted at the rift axis and flow away into the lower lying, evaporite-rich basin, creating a basin stratigraphy of thinly interbedded basalts and evaporites
(Talbot, 2008). The basin infill is significantly thicker than elsewhere in Afar, estimated from controlled source seismic data and limited borehole data, to be up to 5 km-thick (e.g., Makris and Ginzburg, 1987) of mostly Pliocene and younger age rocks (Hutchinson and Engels, 1972).

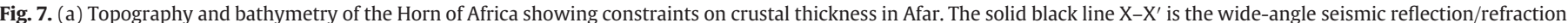

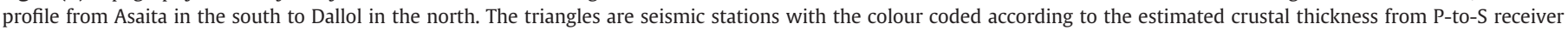

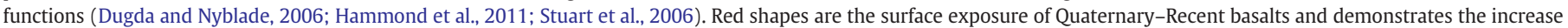

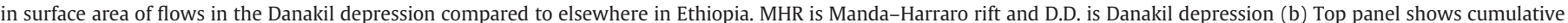

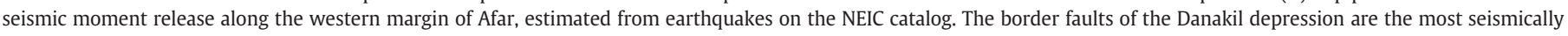

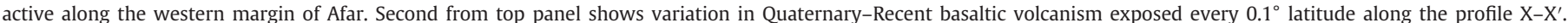

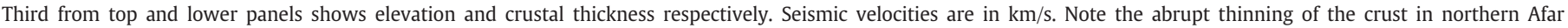
$\left(\sim 13^{\circ} \mathrm{N}\right)$, which coincides with subsidence of the rift valley below sea level and a marked pulse in Quaternary-Recent volcanism.

Modified after Bastow and Keir (2011). 
3.3. Episodes of deformation as windows into extensional and magmatic processes

The joint observation of active volcanic systems in Afar using relatively dense, temporary seismic and GPS deployments, combined with remote sensing techniques such as satellite radar interferometry (InSAR) provides a valuable tool to investigate the sometimes rapid processes responsible for sculpting the geology and surface morphology of the rift. Here we discuss recent observations from the MHR and the Erta Ale range, focussing on constraints they provide on along-rift variations in style of magmatic plumbing systems and crustal extension.

\subsubsection{The 2005-2011 Dabbahu-Manda-Harraro rifting episode}

During 2005, the emplacement of a $60 \mathrm{~km}$-long basaltic magma intrusion beneath the MHR marked the onset of the Dabbahu rifting episode (Ayele et al., 2007a; Wright et al., 2006), and provides rare insights into the magma intrusion and faulting processes during continental breakup. Occurrence of strong (Mw 3.6-5.6) seismicity suggests that the initial intrusions likely occurred during a two-week-long time period of 20 September-4 October (e.g., Ayele et al., 2009). A minor eruption of pumice and ash occurred on 26 September from the Da'Ure vent near Dabbahu. Resorption of sanidine feldspar lathes in the pumice indicates that their growth was interrupted by heating prior to eruption, consistent with a minor silicic reservoir beneath Da'Ure being reheated by the new basaltic intrusion, which triggered the eruption (Ayele et al., 2009; Wright et al., 2006). Three dimensional displacements measured using InSAR showed near symmetrical rift perpendicular opening of up to $8 \mathrm{~m}$, with the flanks of the rift uplifted by up to $2 \mathrm{~m}$, and a $2-3 \mathrm{~km}$ wide graben subsiding by $2-3 \mathrm{~m}$ at the rift centre (Ayele et al., 2007a; Grandin et al., 2009; Wright et al., 2006). Simple elastic models showed that the deformation was consistent with emplacement of $2.5 \mathrm{~km}^{3}$ sub-vertical dike, up to $10 \mathrm{~m}$ thick and intruded into the upper $10 \mathrm{~km}$ of the crust. The dyke did not erupt at the surface, but caused faults to slip by up to $3 \mathrm{~m}$ on networks of normal faults in the shallow crust (Rowland et al., 2007). Despite the sometimes-spectacular displacements observed at the surface, the dike-induced fault slip accounted for less than $10 \%$ of the total deformation (e.g., Grandin et al., 2009; Wright et al., 2006). The temporal migration of seismicity during the event suggests that the majority of the intrusion was fed laterally from the Ado'Ale volcanic complex (AVC) located at the centre of the segment (Ayele et al., 2009), with geodetic data suggesting that the magma reservoir feeding the intrusion is $\sim 10 \mathrm{~km}$ deep (e.g., Hamling et al., 2009).

From June 2006, the initial dike has been followed by a sequence of 13 smaller intrusions, with the most recent in May 2010 (e.g., Ebinger et al., 2010; Wright et al., 2012). These dykes are typically 1-3 m thick, 10-15 km long, and have a cumulative volume of $1 \mathrm{~km}^{3}$ (Grandin et al., 2010; Hamling et al., 2009). Seismicity data show that they were all fed from the AVC and propagated at rates of 0.2-0.6 m/s (Belachew et al., 2011; Grandin et al., 2011; Keir et al., 2009b). As was the case during the September 2005 intrusion, dike-induced faulting accompanied intrusion but made a relatively minor contribution to the total deformation. Three of the later dikes have reached the surface as basaltic fissural eruptions (Ferguson et al., 2010). However, the total erupted volume is a small fraction of that intruded into the crust (Ferguson et al., 2010). In summary, the style of extension and magma plumbing beneath the MHR with deformation dominated by episodic lateral dike intrusion sourced from a relatively deep segment centred magma reservoir (e.g., Ebinger et al., 2010; Grandin et al., 2010; Keir et al., 2009b; Wright et al., 2006, 2012).

\subsubsection{8-2010 basaltic eruptions in the Erta'Ale range}

Recent episodes of deformation in the Erta Ale range captured by satellite remote sensing system are markedly different to the Dabbahu rifting episode: they instead demonstrate the dynamics of shallow ( $1 \mathrm{~km}$-deep) magma storage systems in feeding a large basaltic eruption (Fig. 9). Following the November 2008 basaltic eruption from a fissure on Alu-Dallafilla, Pagli et al. (2012) demonstrated using analysis of InSAR data, that the eruption was accompanied by up to $1.9 \mathrm{~m}$ of subsidence across a $\sim 1 \mathrm{~km}$-wide, $\sim 10 \mathrm{~km}$-long zone beneath the volcanic system (Fig. 9). Modelling of these data showed that the lava was sourced from a $\sim 1 \mathrm{~km}$-deep sill elongated parallel to the strike of the volcanic range. The eruption occurred from a fissure above the eastern flank of the sill, with the estimated erupted volume of $25.4 \times 10^{6} \mathrm{~m}^{3}$. Importantly, only minor pre-eruption inflation of the shallow sill was

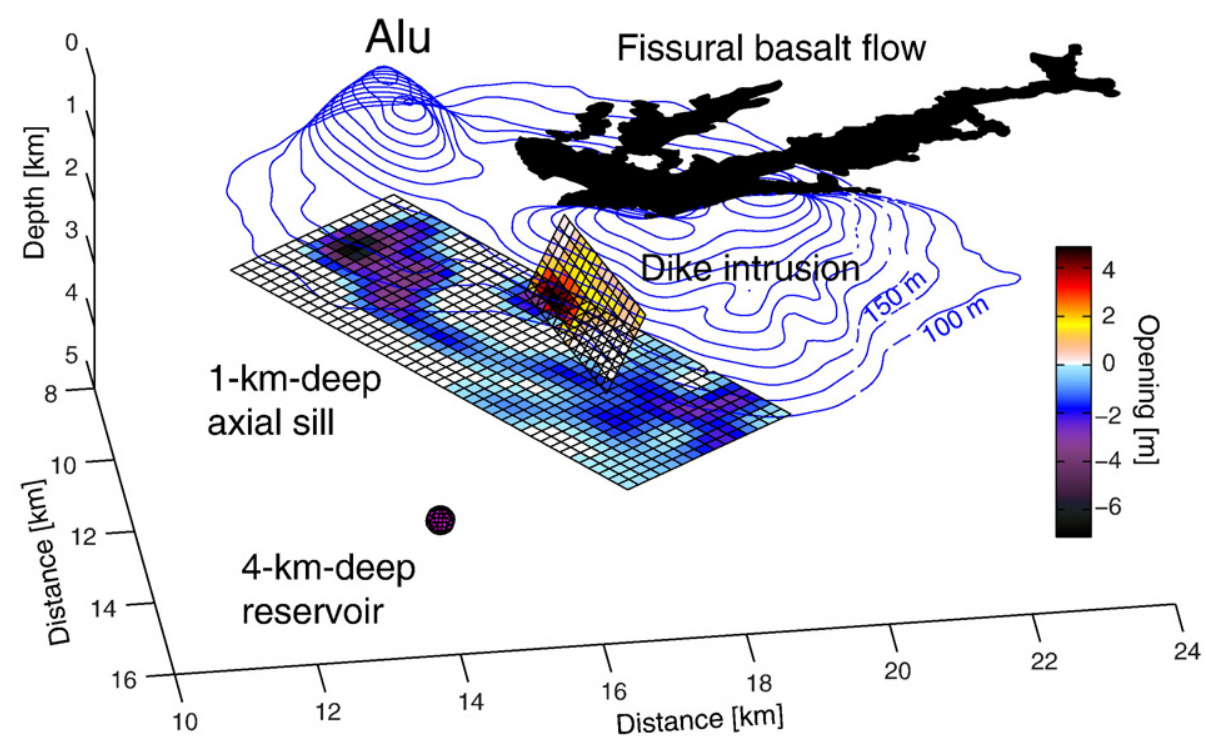

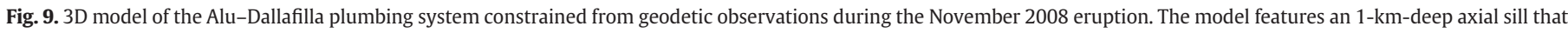

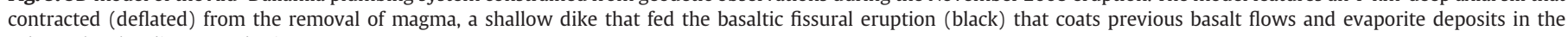
sub-sea-level sedimentary basin. 
observed, suggesting that molten rock was already stored in the shallow undeforming sill.

Additional evidence for shallow magma storage in the Danakil depression comes from recent studies at Erta Ale and Dallol volcanoes. Volatile saturation pressures in lavas erupted during the Erta Ale lava lake overspill in November 2010 are in the range of 7-42 MPa, indicating crystallisation of magma in a shallow ( $<1 \mathrm{~km}$-deep) reservoir beneath the volcano (Field et al., 2012). At Erta Ale, the two active craters sit within a $\sim 3 \mathrm{~km}$-long, $\sim 1 \mathrm{~km}$-wide, $\sim$ NNW elongate caldera (Acocella, 2006), a geometry consistent with the caldera forming after removal of magma from a shallow axial sill similar in shape and depth to that at Alu-Dallafilla. In northernmost Afar, modelling of deformation during October 2004 shows evidence that magma intruded into the rift axis was sourced from a reservoir located $2 \mathrm{~km}$ beneath Dallol (Nobile et al., 2012). These observations along the Erta Ale range provide strong evidence that portions of the rift axis are underlain by relatively long-lived shallow pockets of magma similar to the shallow axial sills mainly found beneath intermediate- to fast-spreading mid ocean ridges (Pagli et al., 2012). The persistence of shallow axial magma chambers at 1-2 km depth beneath the Erta Ale range may be explained by excessive magma supply to the shallow crust and high frequency of magma-chamber replenishment. The lack of vigorous hydrothermal
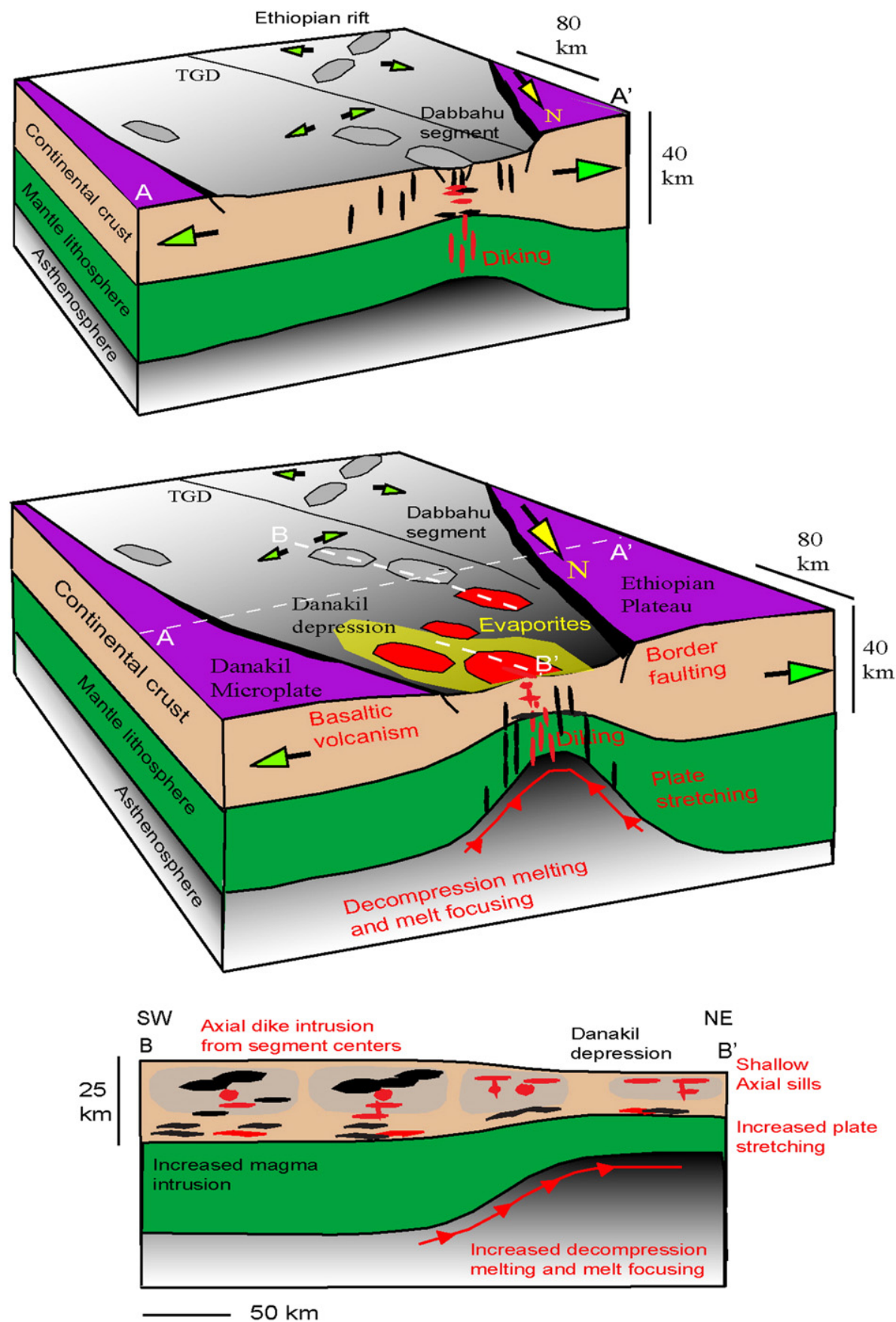

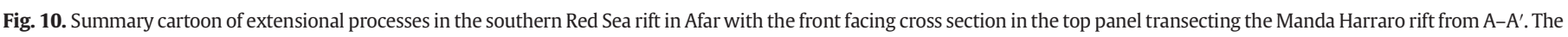

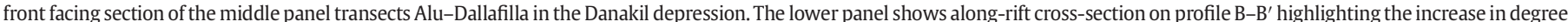

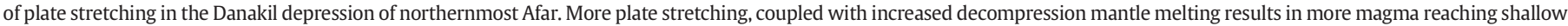

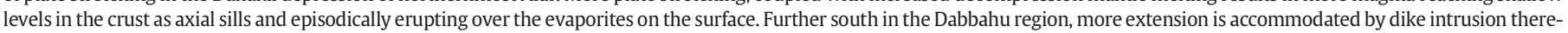
by maintaining thicker plate. In the upper-crust, axial dikes are fed from segment centred, mid-crustal magma reservoirs. 
circulation may also help prevent cooling of shallow magma chambers (Pagli et al., 2012).

\section{Discussion}

\subsection{Links between extension, magmatism, and rift morphology}

The subaerial southern Red Sea rift in Afar shows significant along-rift variations in crustal thickness, elevation, rift morphology, as well as styles of extension and magmatism. The $20-25 \mathrm{~km}$ thick crust beneath the MHR and TG is around twice that predicted by pure shear extension models (e.g., McKenzie, 1978) at the observed extension factor of $\sim 3$ (e.g., Eagles et al., 2004; Redfield et al., 2003). Around $50-60 \%$ of extension is thus likely accommodated by magma intrusion (e.g. Mohr, 1989). In support of this model, high-resolution magnetic and gravity surveys (Bridges et al., 2012) reveal the presence of mafic dikes through the upper crust. Receiver function evidence for elevated bulk-crustal Vp/Vs ratios (Dugda et al., 2005; Hammond et al., 2011), and controlled-source seismic imaging of gabbroic intrusions (Maguire et al., 2006; Makris and Ginzburg, 1987) provide evidence for magma intrusion into the lower crust as well. Evidence for localised dike intrusion accommodating significant crustal strain has important subsequent implications for basin morphology. Fault-slip in the MHR and TG, mainly induced during dike intrusion episodes, creates a relatively narrow graben defined by many long, but small offset normal faults (Rowland et al., 2007; Rubin and Pollard, 1988) (Fig. 10). Both crustal thinning and subsidence of the surface are reduced because of the intrusion of magma.

In the Danakil depression, the observations are markedly different to the MHR and TG. The crust thins abruptly to $\sim 15 \mathrm{~km}$, coincident with subsidence of the land towards and below sea level, and thick sedimentary succession of Pliocene-Recent age ending in evaporites (Figs. 7 and 10). Bastow and Keir (2011) cited these observations as evidence for an abrupt, increase in the proportion of extension via ductile stretching since Pliocene times (Fig. 10). They suggested that protracted heating and weakening of the plate (Te reduces from $\sim 9 \mathrm{~km}$ in the MHR to $\sim 5 \mathrm{~km}$ into Danakil) from previous localised magma intrusion were the reason for the change in extension mechanism.

An increased proportion of mechanical extension at the expense of magma intrusion, is predicted to be manifested as an increased amount of faulting on basin bounding faults in the upper crust (McKenzie, 1978). Both global (e.g., Hagos et al., 2006) and local seismicity catalogues (e.g., Ayele et al., 2007b; Keir et al., 2011a) show the western Afar margin adjacent to the Danakil depression is more seismically active than to the south (Figs. 1 and 7). This adds support to the view that mechanical deformation via mechanical extension (plate stretching and faulting) currently accounts for a higher proportion of lithospheric strain in the Danakil depression than further south in the MHR and TG, where dike intrusion dominates. In addition, the proximity of rift margin border faults to the volcanic axis (in northern-most Afar in particular) may result in close interaction between faulting near the rift margins and magmatic processes nearer to the rift centre (e.g., Nobile et al., 2012; Ogubazghi et al., 2004).

4.2. Implications for magma generation and the formation of seawarddipping reflector sequences

Constraining the phase of plate stretching and thinning to the last 5 Ma has significant implications for the expected volumes of decompression mantle melting (Bastow and Keir, 2011). Larger volumes are predicted during a phase of rapid thinning than during a gradual one spanning the 30 Ma since breakup began (e.g., Bown and White, 1995). Increased mantle melt volumes and the reduction of melt participating in extension by dyke intrusion, mean that larger melt volumes can migrate into shallow magma reservoirs and extrude the thinner and weaker plate (Bastow and Keir, 2011) (Fig. 10). Melting may also be enhanced by stress-driven melt segregation (e.g., Holtzman and Kendall, 2010), and/or small-scale convection (Ligi et al., 2011) induced by steep gradients on the lithosphereasthenosphere boundary beneath the narrow rift.

The plate stretching hypothesis for the Danakil depression presented by Bastow and Keir (2011) is consistent with the style of magmatism observed at volcanoes such as Alu-Dalafilla and Erta Ale (Figs. 7 and 10). Combined petrology and geodesy studies reveal shallow ( 1-2 km deep) magma chambers beneath the topographically prominent rift axis (Pagli et al., 2012) (Figs. 9 and 10). Silicic volcanism is rare, with the basalt-rich geology indicating that parental magmas are stored for shorter periods in the crust prior to eruption (e.g., Rooney et al., 2007, 2011). The relatively long-lived, shallow pockets of magma beneath the Danakil rift axis are reminiscent of the shallow axial sills found beneath intermediate-to-fast spreading ocean ridges (Pagli et al., 2012). The 'ultra-slow' extension rates observed in northern Afar would, alone, be incapable of producing such observations. The late-stage plate thinning observed in Afar (Bastow and Keir, 2011), above the hot underlying mantle (Rooney et al., 2012a,b) is thus the most likely explanation for the observed increase in magma supply to shallow reservoirs and consequent formation of an axial-high rift morphology.

The igneous geological record of the Danakil region is dominated by Quaternary-to-Recent low viscosity basalts that often flow several kilometres away from topographically prominent, heavily fissured axial volcanic edifices such as Erta Ale and Alu-Dalafilla. They cover younger basaltic flows and evaporite-rich sediments deposited adjacent to shield volcanoes that are progressively burying the heavily stretched and intruded Afar crust beneath (Figs. 7 and 10). The Quaternary geology of the Danakil region is similar to that which is often inferred for the COT at magmatic rifted margins on the basis of seismic data: highly reflective sequences, usually termed sea-ward dipping reflectors (SDRs) reflect a large proportion of the controlled source seismic energy used to image them back to the surface (Maresh and White, 2005; Mutter, 1985; Mutter et al., 1982; White et al., 2008). The along-rift variation in rifting processes in the subaerial Red Sea rift in Afar suggests that an abrupt phase of plate stretching just prior to the onset of seafloor spreading can induce dramatic subsidence of a magmatic rift below sea-level (Bastow and Keir, 2011). It can also prompt the development of large volume of decompression melt in the mantle that are required to explain the pulse in basaltic volcanism observed at magmatic margins. In the north Atlantic for example, volumes of erupted lava increased by an order of magnitude during a phase of lithospheric thinning leading to breakup at 56.1-55 Ma (Storey et al., 2007). These lavas are mostly subaerial basalts forming the seaward dipping reflector sequences and interpreted to have formed during a $\sim 1$ Myr long pulse in shallow decompression melting (Storey et al., 2007).

\subsection{Future research}

The evidence from Ethiopia thus shows directly that changes in the proportion of extension achieved by magma intrusion versus plate stretching fundamentally control rates of decompression melting in the mantle, as well as volumes and style of volcanism observed at the surface. (Fig. 10). The challenge now is thus to understand better when and why faulting, stretching and magma intrusion evolve as they do during the development of the continent-ocean transition. Combining, these mechanisms of strain in new rifting models, rather than isolating them, and appreciating how plate strength varies during rifting are vital in developing a more complete understanding of the geological record that documents continental breakup over time. 
To achieve these aims we need improved quantitative constraints on spatial and temporal variations in rates and mechanisms of lithospheric deformation. In Afar for example, we currently lack detailed geodetic constraints across the present day plate boundary zone, such geodesy campaigns are routine in Iceland, for example (e.g., Arnadottir et al., 2009; LaFemina et al., 2005). Also of fundamental importance to understanding rates of decompression melting and margin subsidence are improved constraints on the variation of lithospheric thickness over time during the rifting to spreading process (e.g., Huismans and Beaumont, 2011). Ongoing petrological and geochemical studies aiming to understand the evolution of Miocene-Recent magma from the asthenosphere to the surface promise to quantify the melting regime during breakup.

\section{Summary}

We have combined geological, geodetic and geophysics constraints on extensional processes in the Afar depression in order to understand spatial and temporal variations in magma intrusion and ductile plate stretching. Our synthesis shows that there is a fundamental change in axial rift morphology from a narrow fault bound graben in central Afar to a topographically prominent axial volcanic range in the Danakil depression of northernmost Afar. The variation in morphology is spatially coincident with marked thinning of the crust, an increase in young basalt flows coupled with presence of exceptionally shallow axial magma chambers, and subsidence of the land surface towards and below sea-level. The variations can be attributed to a northward increase in proportion of extension by ductile plate stretching at the expense of magma intrusion, most likely in response to a longer history of localised heating and weakening. Our analysis implies that ductile stretching of heavily intruded continental crust is a fundamental process during the latest stages of continental breakup, with the increased decompression melting and reduction in magma intruded into the plate resulting in large volumes of basalts reaching shallow levels in the crust and erupting at the surface. The similarity in geology of northernmost Afar to the thick sequences of basalt flows and evaporites common at volcanic margins worldwide means that the processes active today in the Danakil depression are a modern analogue for those responsible for formation of seaward-dipping reflector sequences.

\section{Acknowledgements}

We thank Giacomo Corti, Gwenn Peron-Pinvidic, and an anonymous reviewer for their constructive comments on the manuscript. We also thank Cindy Ebinger, Tyrone Rooney, Liz Baker, Atalay Ayele, Tim Wright and the Afar Rift Consortium for interesting discussions regarding the breakup of Afar. The advice and assistance provided by Sarah Wormald and Casey Nixon in creating figure 8 is much appreciated. IB is funded by the Leverhulme Trust. Part of this work is supported by Natural Environment Research Council grants NE/D008611/1, NE/D01039X/1 and NE/E007414/1.

\section{References}

Abebe, T., Balestrieri, M.L., Bigazzi, G., 2010. The central Main Ethiopian rift is younge than $8 \mathrm{Ma}$ : confirmation through apatite fission-track thermochronology. Terra Nova 22, 470-476 http://dx.doi.org/10.1111/j.1365-3121.2010.00968.

Acocella, V., 2006. Regional and local tectonics at Erta Ale caldera, Afar (Ethiopia). Journa of Structural Geology 28, 1808-1820 http://dx.doi.org/10.1016/j.jsg.2006.06.014.

Acocella, V., 2010. Coupling volcanism and tectonics along divergent plate boundaries: collapsed rifts from central Afar, Ethiopia. Geological Society of America Bulletin 122, 1717-1728 http://dx.doi.org/10.1130/B30105.1.

Acocella, V., Abebe, B., Korme, T., Barberi, F., 2008. Structure of Tendaho Graben and Manda Hararo Rift: implications for the evolution of the southern Red Sea propagator in Central Afar. Tectonics 27, TC4016 http://dx.doi.org/10.1029/2007TC002236.

Agostini, A., Bonini, M., Corti, G., Sani, F., Manetti, P., 2011a. Distribution of Quaternary deformation in the central Main Ethiopian Rift, East Africa. Tectonics 30, TC4010.

Agostini, A., Bonini, M., Corti, G., Sani, F., Mazzarini, F., 2011b. Fault architecture in the Main Ethiopian Rift and comparison with experimental models: Implications for rift evolution and Nubia-Somalia kinematics. Earth and Planetary Science Letters 301, 479-492.
Arnadottir, T., Lund, B., Jiang, W., Geirsson, H., Bjornsson, H., Einarsson, P., Sigurdsson, T., 2009. Glacial rebound and plate spreading: results from the first countrywide GPS observations in Iceland. Geophysical Journal International 177, 671-716.

ArRajehi, A., McClusky, S., Reilinger, R., Daoud, M., Alchalbi, A., Ergintav, Gomez, F., Sholan, J., Bou-Rabee, F., Ogubazghi, G., Haileab, B., Fisseha, S., Asfaw, L., Mahmoud, S., Rayan, A., Bendik, R., Kogan, L., 2010. Geodetic constraints on present-day motion of the Arabian Plate: implications for Red Sea and Gulf of Aden rifting. Tectonics 29, TC3011 http://dx.doi.org/10.1029/2009TC002482.

Audin, L., Quidelleur, X., Coulie, E., Courtillot, V., Gilder, S., Manighetti, I., Gillot, P.-Y., Tapponnier, P., Kidane, T., 2004. Palaeomagnetism and $\mathrm{K}-\mathrm{Ar}$ and ${ }^{40} \mathrm{Ar} /{ }^{39} \mathrm{Ar}$ ages in the Ali Sabieh area (Republic of Djibouti and Ethiopia): constraints on the mechanism of Aden ridge proagation into southeastern Afar during the last $10 \mathrm{Myr}$. Geophysical Journal International 158, 327-345 http://dx.doi.org/10.1111/j.1365246X.2004.02286.X.

Ayalew, D., Ebinger, C., Bourdon, E.., Wolfenden, E., Yirgu, G., Grassineau, N., 2006. Temporal compositional variation of syn-rift rhyolites along the western margin of the southern Red Sea and northern Main Ethiopian rift. Geological Society of London Special Publication 259, 121-130 http://dx.doi.org/10.1144/GSL.SP.2006.259.01.10.

Ayele, A., Stuart, G., Kendall, J.-M., 2004. Insights into rifting from shear-wave splitting and receiver functions: an example from Ethiopia. Geophysical Journal International 157, 354-362 http://dx.doi.org/10.1111/j.1365-246X.2004.02206.X.

Ayele, A., Jacques, E., Kassim, M., Kidane, T., Omar, A., Tait, S., Nercessian, A., de Chabalier, J.-B., King, G., 2007a. The volcano-seismic crisis in Afar, Ethiopia, starting September 2005. Earth and Planetary Science Letters 255, 177-187.

Ayele, A., Stuart, G., Bastow, I., Keir, D., 2007b. The August 2002 earthquake sequence in north Afar: insights into the neotectonics of the Danakil microplate. Journal of African Earth Sciences 40, 70-79.

Ayele, A., Keir, D., Ebinger, E., Wright, T.J., Stuart, G.W., Buck, W.R., Jacques, E., Ogubazghi, G., Sholan, J., 2009. September 2005 mega-dike emplacement in the Manda-Harraro nascent oceanic rift (Afar depression). Geophysical Research Letters 36, L20306 http://dx.doi.org/10.1029/2009GL039605.

Baker, J., Snee, L., Menzies, M., 1996. A brief Oligocene period of flood volcanism in Yemen. Earth and Planetary Science Letters 138, 39-55.

Barberi, F., Varet, J., 1970. The Erta Ale volcanic range (Danakil depression, northern Afar, Ethiopia). Bulletin of Volcanology 34, 848-917.

Barberi, F. Varet, J., 1977. Volcanism of Afar: small-scale plate tectonics implications. Geological Society of America Bulletin 88, 1251-1266 http://dx.doi.org/10.1130/ 0016-7606(1977) 88<1251:VOASP $>2.0 . C 0 ; 2$

Barberi, F., Borsi, S., Ferrara, G., Marinelli, G., Santacroce, R., Tazieff, H., Varet, J., 1972. Evolution of the Danakil Depression (Afar, Ethiopia) in light of radiometric age determinations. Journal of Geology 80, 720-729.

Bastow, I., 2012. Relative travel-time upper-mantle tomography and the elusive background mean. Geophysical Journal International 190, 1271-1278 http://dx.doi.org/ 10.1111/j.1365-246X.2012.05559.x.

Bastow, I.D., Keir, D., 2011. The protracted development of the continental-ocean transition in Afar. Nature Geoscience 4, 248-250 http://dx.doi.org/10.1038/NGE01095.

Bastow, I.D., Nyblade, A.A., Stuart, G.W., Rooney, T.O., Benoit, M.H., 2008. Upper mantle seismic structure beneath the Ethiopian hotspot: rifting at the edge of the African low velocity anomaly. Geochemistry, Geophysics, Geosystems 9 (12), Q12022 http://dx.doi.org/10.1029/2008GC002107.

Bastow, I.D., Pilidou, S., Kendall, J.-M., Stuart, G.W., 2010. Melt-induced seismic anisotropy and magma assisted rifting in Ethiopia: evidence from surface waves. Geochemistry, Geophysics, Geosystems 10, Q0AB05 http://dx.doi.org/10.1029/2010GC003036.

Bastow, I.D., Keir, D., Daly, E., 2011. The Ethiopia afar geoscientific lithospheric experiment (EAGLE): probing the transition from continental rifting to incipient seafloor spreading. Geological Society of America Special Papers 478, 51-76 http:// dx.doi.org/10.1130/2011.2478(04.

Beccaluva, L., Bianchini, G., Natali, C., Siena, F., 2009. Continental flood basalts and mantle plumes: a case study of the northern Ethiopian plateau. Journal of Petrology http://dx.doi.org/10.1093/petrology/egp024.

Belachew, M., Ebinger, C., Cote, D., Keir, D., Rowland, J.V., Hammond, J.O.S., Ayele, A., 2011. Comparison of dike intrusions in an incipient seafloor-spreading segment in Afar, Ethiopia: seismicity perspectives. Journal of Geophysical Research 116, B06405 http://dx.doi.org/10.1029/2010JB007908.

Benoit, M., Nyblade, A.A., VanDecar, J., 2006. Upper mantle P wavespeed variations beneath Ethiopia and the origin of the Afar hotspot. Geology 34 (5), 329-332.

Berckhemer, H., Baier, B., Bartlesen, H., Behle, A., Burkhardt, H., Gebrande, H., Makris, J., Menzel, H., Miller, H., Vees, R., 1975. Deep seismic soundings in the Afar region and on the highland of Ethiopia. In: Pilger, A., Rösler, A. (Eds.), Afar Depression of Ethiopia, Schweizerbart, Stuttgart, I, pp. 89-107.

Beutel, E. Van Wijk, J. Ebinger, C. Keir, D., Agostini, A, 2010. Formation and stability of magmatic segments in the Main Ethiopian and Afar rifts. Earth and Planetary Science Letters 293, 225-235 http://dx.doi.org/10.1016/j.epsl.2010.02.006.

Beyene, A., Abdelsalam, M.G., 2005. Tectonics of the Afar depression: a review and synthesis. Journal of African Earth Sciences 41, 41-59.

Bialas, R.W., Buck, W.R., Qin, R., 2010. How much magma is required to rift a continent? Earth and Planetary Science Letters 292, 68-78 http://dx.doi.org/ 10.1016/j.epsl.2010.01.021.

Biggs, J., Bastow, I.D., Keir, D., Lewi, E., 2011. Pulses of deformation reveal frequently recurring shallow magmatic activity beneath the main Ethiopian rift. Geochemistry, Geophysics, Geosystems 12, Q0AB10 http://dx.doi.org/10.1029/2011GC003662.

Bina, C.R., Wood, B.J., 1987. Olivine-spinel transitions - experimental and thermodynamics constraints and implications for the nature of the $400-\mathrm{km}$ seismic discontinuity. Journal of Geophysical Research 92, 4853-4866.

Bonatti, E., Emiliani, C., Ostlung, G., Rydell, H., 1971. Final desiccation of the Afar rift, Ethiopia. Science 172, 468-469. 
Bonini, M., Corti, G., Innocenti, F., Manetti, P., Mazzarini, F., Abebe, T., Pecskay, Z., 2005 Evolution of the Main Ethiopian rift in the frame of Afar and Kenya rift propagation. Tectonics 24, TC1007 http://dx.doi.org/10.1029/2004TC001680.

Bosworth, W., Huchon, P., McClay, K., 2005. The Red Sea and Gulf of Aden Basins. Journal of African Earth Sciences 43, 334-378 http://dx.doi.org/10.1016/j.afrearsci.2005.07.020.

Bown, J.W., White, R.S., 1995. Effect of finite extension rate on melt generation at rifted continental margins. Journal of Geophysical Research 100, 18011-18029.

Bridges, D.L., Mickus, K., Gao, S.S., Abdelsalam, M.G., Alemu, A., 2012. Magnetic stripes of a transitional continental rift in Afar. Geology http://dx.doi.org/10.1130/G32697.1.

Burke, K., 1996. The African plate. South African Journal of Geology 99, 339-409.

Chernet, T., Hart, W.K., Aronson, J.L., Walter, R.C., 1998. New age constraints on the timing of volcanism and tectonism in the northern Main Ethiopian Rift-southern Afar transition zone (Ethiopia). Journal of Volcanology and Geothermal Research 80, 267-280.

Cornwell, D., Mackenzie, G., England, R., Maguire, P., Asfaw, L., Oluma, B., 2006. Northern main Ethiopian rift crustal structure from new high-precision gravity data. Geological Society of London Special Publication 259, 307-321.

Cornwell, D., Hetenyi, G., Blanchard, T., 2011. Mantle transition zone variations beneath the Ethiopian rift and Afar: chemical heterogeneity within a hot mantle? Geophysical Research Letters 38 (16), L16308 http://dx.doi.org/10.1029/2011GL047575.

Corti, G., 2008. Control of rift obliquity on the evolution and segmentation of the main Ethiopian rift. Nature Geoscience 1, 258-262 http://dx.doi.org/10.1038/ngeo160.

Corti, G., 2009. Continental rift evolution: from rift initiation to incipient break-up in the Main Ethiopian Rift, East Africa. Earth-Science Reviews 96, 1-53 http:// dx.doi.org/10.1016/j.earscirev.2009.06.005.

Courtillot, V., Jaupart, C., Manighetti, I., Tapponnier, P., Besse, J., 1999. On causal links between flood basalts and continental breakup. Earth and Planetary Science Letters 166, 177-195.

Craig, T.J., Jackson, J.A., Priestley, K., McKenzie, D., 2011. Earthquake distribution patterns in Africa: their relationship to variations in lithospheric and geologic structure, and their rheological implications. Geophysical Journal International 185 , 403-434 http://dx.doi.org/10.1111/j.1365-246X.2011.04950.x.

Daly, E., Keir, D., Ebinger, C.J., Stuart, G.W., Bastow, I.D., Ayele, A., 2008. Crustal tomographic imaging of a transitional continental rift: the Ethiopian rift. Geophysical Journal International 172, 1033-1048 http://dx.doi.org/10.1111/j.1365-246X.2007.03682.x.

Daradich, A., Mitrovica, J., Pysklywec, R., Willett, S., Forte, A., 2003. Mantle flow, dynamic topography, and rift-flank uplift of Arabia. Geology 31 (10), 901-904.

Debayle, E., Lévêque, J., Cara, M., 2001. Seismic evidence for a deeply rooted lowvelocity anomaly in the upper mantle beneath the northeastern Afro/Arabian continent. Earth and Planetary Science Letters 193, 423-436.

Dick, H.J.B., Lin, J., Schouten, H., 2003. An ultraslow-spreading class of ocean ridge. Nature 426, 405-412.

Dugda, M.T., Nyblade, A.A., 2006. New constraints on crustal structure in eastern Afar from the analysis of receiver functions and surface wave dispersion in Djibouti. Geological Society of London Special Publication 259, 239-251.

Dugda, M., Nyblade, A., Juliá, J., Langston, C., Ammon, C., Simiyu, S., 2005. Crustal structure in Ethiopia and Kenya from receiver function analysis. Journal of Geophysical Research 110 (B1) http://dx.doi.org/10.1029/2004JB003065.

Dunn, R., Toomey, D., 1997. Seismological evidence for three-dimensional melt migration beneath the East Pacific rise. Nature 388, 259-262.

Dziak, R., Bohnenstiehl, D., Matsumoto, H., Fox, C., Smith, D., Tolstoy, M., Lau, T., Haxel, J., Fowler, M., 2004. P- and T-wave detection thresholds, Pn velocity estimate, and detection of lower mantle and core P-waves on ocean sound-channel hydrophones at the Mid-Atlantic ridge. Bull. Seism. Soc. Am. 94 (2), 665-677.

Dziewonski, A.D., Anderson, D.L., 1981. Preliminary reference Earth model. Physics of the Earth and Planetary Interiors 25, 297-356.

Eagles, G., Gloaguen, R., Ebinger, C.J., 2004. Kinematics of the Danakil microplate. Earth and Planetary Science Letters 203, 607-620.

Ebinger, C., 2005. Continental breakup: the East Africa perspective. Astronomy and Geophysics 46, 16-21.

Ebinger, C.J., Casey, M., 2001. Continental breakup in magmatic provinces: an Ethiopian example. Geology 29, 527-530 http://dx.doi.org/10.1130/0091-7613(2001) 029<0527: CBIMPA $>2.0$. CO;2.

Ebinger, C., Hayward, N., 1996. Soft plates and hot spots: views from Afar. Journal of Geophysical Research 101, 21859-21876 http://dx.doi.org/10.1029/96JB02118.

Ebinger, C., Sleep, N., 1998. Cenozoic magmatism throughout East Africa resulting from impact of a single plume. Nature 395, 788-791.

Ebinger, C.J., Yemane, T., WoldeGabriel, G., Aronson, J., Walter, R., 1993. Eocene-Recent volcanism and faulting in the southern Main Ethiopian Rift. Journal of the Geological Society of London 150, 99-108 http://dx.doi.org/10.1144/gsjgs.150.1.0099.

Ebinger, C., Ayele, A., Keir, D., Rowland, J., Yirgu, G., Wright, T., Belachew, M., Hamling, I., 2010. Length and timescales of rift faulting and magma intrusion: the Afar rifting cycle from 2005 to present. Annual Reviews of Earth and Planetary Science 38, 437-464 http://dx.doi.org/10.1146/annurev-earth-040809-152333.

Ferguson, D.J., Barnie, T.D., Pyle, D.M., Oppenheimer, C., Yirgu, G., Lewi, E., Kidane, T., Carn, S., Hamling, E., 2010. Recent rift-related volcanism in Afar, Ethiopia. Earth and Planetary Science Letters 292, 409-418 http://dx.doi.org/10.1016/j.epsl.2010.02.010.

Fernandes, R.M.S., Ambrosius, B.A.C., Noomen, R., Bastos, L., Combrinck, L., Miranda, J.M., Spakman, W., 2004. Angular velocities of Nubia and Somalia from continuous GPS data: implications on present-day relative kinematics. Earth and Planetary Science Letters 222, 197-208 (10.1016j.epsl.2004.02.008).

Field, L., Barnie, T., Blundy, J., Brooker, R.A., Keir, D., Lewi, E., 2012. Integrated field, satellite and petrological observations of the November 2010 eruption of Erta Ale. Bulletin of Volcanology http://dx.doi.org/10.1007/s00445-012-0660-7.

Fishwick, S., Bastow, I.D., 2011. Towards a better understanding of African topography: a review of passive-source seismic studies of the African crust and upper mantle.
Ceological Society of London Special Publications 357, 343-371 http://dx.doi.org/ 10.1144/SP357.19.

Forte, A., Moucha, R., Simmons, N., Grand, S., Mitrovica, J., 2010. Deep-mantle contributions to the surface dynamics of the North American continent. Tectonophysics 481, 3-15 http://dx.doi.org/10.1016/j.tecto.2009.06.010.

Furman, T., Bryce, J., Hanan, B., Yirgu, G., Ayalew, D., 2006. Heads and tails: 30 years of the Afar plume, in the Afar Volcanic Province within the East African Rift System. Geological Society of London Special Publication 259, 95-119.

Gao, S., Liu, K., Abdelsalam, M., 2010. Seismic anisotropy beneath the Afar depression and adjacent areas: implications for mantle flow. Journal of Geophysical Research 115 (B12), B12330.

George, R., Rogers, N., Kelley, S., 1998. Earliest magmatism in Ethiopia: evidence for two mantle plumes in one continental flood basalt province. Geology 26, 923-926.

Ghebreab, W., 1998. Tectonics of the Red Sea region reassessed. Earth-Science Reviews $45,1-44$.

Grand, S., 2002. Mantle shear-wave tomography and the fate of subducted slabs. Royal Society of London Philosophical Transactions Series A 360, 2475-2491.

Grandin, R., Socquet, A., Binet, R., Klinger, Y., Jacques, E., de Chabalier, J.-B., King, G.C.P. Lasserre, C., Tait, S., Tapponier, P., Delorme, A., Pinzuti, P., 2009. September 2005 Manda Harraro-Dabbahu rifting event, Afar (Ethiopia): constraints provided by geodetic data. Journal of Geophysical Research 114, B08404 http://dx.doi.org/ 10.1029/2008JB05843.

Grandin, R., Socquet, A., Jacques, E., Mazzoni, N., de Chabalier, J.-B., King, G.C.P., 2010 Sequence of rifting in Afar, Manda-Hararo rift, Ethiopia, 2005-2009. Time-space evolution and interactions between dikes from interferometric synthetic aperture radar and static stress change modeling. Journal of Geophysical Research 115 B10413 http://dx.doi.org/10.1029/2009JB000815.

Grandin, R., Jacques, E., Nercessian, A., Ayele, A., Doubre, C., Socquet, A., Keir, D., 2011 Seismicity during lateral dike propagation: Insights from new data in the recen Manda Hararo-Dabbahu rifting episode (Afar, Ethiopia). Geochemistry, Geophysics, Geosystems 12, Q0AB08 http://dx.doi.org/10.1029/2010GC003434.

Hagos, L., Arvidsson, R., Roberts, R., 2006. Application of the spatially smoothed seismicity and Monte Carlo methods to estimate the seismic hazard of Eritrea and the surrounding region. Natural Hazards 39, 395-418 http://dx.doi.org/10.1007/ s11069-005-6127-9.

Hamling, I.J., Ayele, A., Bennati, L., Calais, E., Ebinger, C.J., Keir, D., Lewi, E., Wright, T.J. Yirgu, G., 2009. Geodetic observations of the ongoing Dabbahu rifting episode: new dyke intrusions in 2006 and 2007. Geophysical Journal International 178, 989-1003 http://dx.doi.org/10.1111/j.1365-246X.2009.04163.x.

Hammond, J.O.S., Kendall, J.-M., Stuart, G.W., Keir, D., Ebinger, C., Ayele, A., Belachew, M., 2011. The nature of the crust beneath the Afar triple junction: evidence from receiver functions. Geochemistry, Geophysics, Geosystems 12, Q12004 http:/ dx.doi.org/10.1029/2011GC003738.

Hansen, S., Nyblade, A., Benoit, M., 2012. Mantle structure beneath Africa and Arabia from adaptively parameterized P-wave tomography: implications for the origin of Cenozoic Afro-Arabian tectonism. Earth and Planetary Science Letters 319, 23-34.

Hayward, N.J., Ebinger, C.J., 1996. Variations in the along-axis segmentation of the Afar Rift system. Tectonics 15, 244-257 http://dx.doi.org/10.1029/95TC02292.

Helffrich, G., 2000. Topography of the transition zone seismic discontinuities. Reviews of Geophysics 38 (1), 141-158.

Hofmann, C., Courtillot, V., Feraud, G., Rochette, P., Yirgu, G., Ketefo, E., Pik, R., 1997 Timing of the Ethiopian flood basalt event and implications for plume birth and global change. Nature 389, 838-841.

Holtzman, B.K., Kendall, J.-M., 2010. Organized melt, seismic anisotropy and plate boundary lubrication. Geochemistry, Geophysics, Geosystems 11, Q0AB06.

Huismans, R., Beaumont, C., 2011. Depth-dependent extension, two-stage breakup and cratonic underplating at rifted margins. Nature 473, 74-78.

Hutchinson, R.W., Engels, G.G., 1972. Tectonic evolution of the southern Red Sea and its possible significance to older rifted continental margins. Geological Society of America Bulletin 83, 2989-3002.

Jestin, F., Huchon, P., Gaulier, J.-M., 1994. The Somalia plate and the East African rift system: present-day kinematics. Geophysical Journal International 116, 637-654 http://dx.doi.org/10.1111/j.1365-246X.1994.tb03286.x.

Keir, D., Bastow, ID. Whaler, KA. Daly, E. Cornwell, D.G., Hautot, S., 2009a. Lower crustal earthquakes near the Ethiopian rift induced by magmatic processes. Geochemistry, Geophysics, Geosystems 10, Q0AB02 http://dx.doi.org/10.1029/2009GC002382.

Keir, D., Hamling, I.J., Ayele, A., Calais, E., Ebinger, C., Wright, T.J., Jacques, E., Mohamed, K., Hammond, J.O.S., Belachew, M., Baker, E., Rowland, J.V., Lewi, E., Rowland, J.V. Lewi, E., Bennati, L., 2009b. Evidence for focused magmatic accretion at segment centres from lateral dike injections beneath the Red Sea rift in Afar. Geology 37, 59-62 http://dx.doi.org/10.1130/G25147A.1.

Keir, D., Belachew, M., Ebinger, C.J., Kendall, J.-M., Hammond, J.O.S., Stuart, G.W., Ayele A., Rowland, J.V., 2011a. Mapping the evolving strain field during continental breakup from crustal anisotropy in the Afar Depression. Nature Communications 2, 285 http://dx.doi.org/10.1038/ncomms1287.

Keir, D., Pagli, C., Bastow, I.D., Ayele, A., 2011b. The magma-assisted removal of Arabia in Afar: evidence from dike injection in the Ethiopian rift captured using InSAR and seismicity. Tectonics 30, TC2008 http://dx.doi.org/10.1029/2010TC002785.

Kendall, J.-M., Stuart, G.W., Ebinger, C., Bastow, I., Keir, D., 2005. Magma assisted rifting in Ethiopia. Nature 433, 146-148.

Kendall, J.-M., Pilidou, S., Keir, D., Bastow, I., Stuart, G., Ayele, A., 2006. Mantle upwellings, melt migration and the rifting of Africa: insights from seismic anisotropy. Geological Society of London Special Publication 259, 55-72.

Keranen, K., Klemperer, S.L., Gloaguen, R., EAGLE Working Group, 2004. Three-dimensional seismic imaging of a protoridge axis in the Main Ethiopian rift. Geology 32 949-952 http://dx.doi.org/10.1130/G20737.1. 
Kieffer, B., Arndt, N., Lapierre, H., Bastien, F., Bosch, D., Pecher, A., Yirgu, G., Ay alew, D. Weiss, D., Jerram, D., et al., 2004. Flood and Shield Basalts from Ethiopia: magmas from the African superswell. Journal of Petrology 45 (4), 793-834

LaFemina, P.C., Dixon, T.H., Malservisi, R., Arnadottir, T., Sturkell, E., Sigmundsson, F. Einarsson, P., 2005. Geodetic GPS measurements in south Iceland: strain accumulation and partitioning in a propagating ridge system. Journal of Geophysical Research 110, B11405.

Lahitte, P., Gillot, P.-Y., Courtillot, V., 2003a. Silicic central volcanoes as precursors to rift propagation: the Afar case. Earth and Planetary Science Letters 207, 103-116.

Lahitte, P., Gillot, P.-Y., Kidane, T., Courtillot, V., Abebe, B., 2003b. New age constraints on the timing of volcanism in Central Afar, in the presence of propagating rifts. Journal of Geophysical Research 108 http://dx.doi.org/10.1029/2001JB001689.

Leroy, S., d'Acremont, E., Tiberi, C., Basuyau, F., Lucazeau, F., Sloan, H., 2010. Recent offaxis volcanism in the eastern Gulf of Aden: implications for plume-ridge interaction. Earth and Planetary Science Letters 293, 140-153 http://dx.doi.org/10.1016/ j.epsl.2010.02.036.

Li, C., van der Hilst, R., Engdahl, R., Burdick, S., 2008. A new global model for P wave speed variations in Earth's mantle. Geochemistry, Geophysics, Geosystems 9 (5), 21 http://dx.doi.org/10.1029/2007GC001806.

Ligi, M., et al., 2011. Initial burst of oceanic crust accretion in the Red Sea due to edge driven mantle convection. Geology 39, 1019-1022 http://dx.doi.org/10.1130/G32243.1.

Mackenzie, G., Thybo, H., Maguire, P.K.H., 2005. Crustal velocity structure across the main Ethiopian rift: results from 2-dimensional wide-angle seismic modeling. Geophysical Journal International 162, 994-1006 http://dx.doi.org/10.1111/j.1365-246X.2005 02710.x.

Maguire, P.K.H., Keller, G.R., Klemperer, S.L., Mackenzie, G.D., Keranen, K., Harder, S., O'Reilly, B., Thydo, H., Asfaw, L., Khan, M.A., Amha, M., 2006. Crustal structure of the northern main Ethiopian rift from the EAGLE controlled-source survey; a snapshot of incipient lithospheric break-up. Geological Society of London Special Publication 259, 269-291.

Makris, J., Ginzburg, A., 1987. The Afar depression: transition between continental rifting and sea-floor spreading. Tectonophysics 141, 199-214.

Manighetti, I., Tapponnier, P., Courtillot, V., Grszow, S., Gillot, P.-Y., 1997. Propagation of rifting along the Arabia-Somalia plate boundary: the Gulfs of Aden and Tadjoura. Journal of Geophysical Research 102, 2681-2710 http://dx.doi.org/ 10.1029/96JB01185.

Manighetti, I., Tapponier, P., Courtillot, V., Gallet, Y., Jacques, E., Gillot, P.Y., 2001. Strain transfer between disconnected, propagating rifts in Afar. Journal of Geophysical Research 106, 13613-13665 http://dx.doi.org/10.1029/2000JB900454.

Maresh, J., White, R., 2005. Seeing through a glass, darkly: strategies for imaging through basalt. First Break 23, 27-33.

Mazzarini, F., 2008. Vent distribution and crustal thickness in stretched continental crust: the case of the Afar Depression (Ethiopia). Geosphere 3, 152-162 http:// dx.doi.org/10.1130/GES00070.1.

McClusky, S., et al., 2010. Kinematics of the southern Red Sea-Afar Triple junction and implications for plate dynamics. Geophysical Research Letters 37, L05301 http:// dx.doi.org/10.1029/2009GL041127.

McKenzie, D., 1978. Some remarks on the development of sedimentary basins. Earth and Planetary Science Letters 40, 25-32 http://dx.doi.org/10.1016/0012-821X(78)90071-7.

McKenzie, D.P., Davies, D., Molnar, P., 1970. Plate tectonics of the Red Sea and East Africa. Nature 226, 243-248.

Mohr, P.A., 1967. Major volcano-tectonic lineament in the Ethiopian rift system. Nature 213, 664-665 http://dx.doi.org/10.1038/213664a0.

Mohr, P.A., 1970. The Afar triple junction and seafloor-spreading. Journal of Geophysical Research 75, 7340-7352.

Mohr, P.A., 1989. Nature of the crust under Afar: new igneous, not thinned continental. Tectonophysics $167,1-11$.

Moucha, R., Forte, A., 2011. Changes in African topography driven by mantle convection. Nature Geoscience 4 (10), 707-712.

Mutter, J., 1985. Seaward dipping reflectors and the continent-ocean boundary at passive continental margins. Tectonophysics 114, 117-131 http://dx.doi.org/10.1016/ 0040-1951(85)90009-5

Mutter, J., Talwani, M., Stoffa, P., 1982. Origin of seaward-dipping reflectors in oceanic crust off the Norwegian margin by "subaerial seafloor spreading". Geology 10 , 353-357 http://dx.doi.org/10.1130/0091-7613(1982) 10<353:OOSRIO>2.0.CO;2.

Nobile, A., Pagli, C., Keir, D., Wright, T.J., Ayele, A., Ruch, J., Acocella, V., 2012. Dike-fault interaction during the 2004 Dallol intrusion at the northern edge of the Erta Ale Ridge (Afar, Ethiopia). Geophysical Research Letters http://dx.doi.org/10.1029/2012GL053151.

Obrebski, M., Kiselev, S., Vinnik, L., Montagner, J.-P., 2010. Anisotropic stratification beneath Africa from joint inversion of SKS and P receiver functions. Journal of Geophysical Research 115, B09313 http://dx.doi.org/10.1029/2009JB006923.

Ogubazghi, G.W., Ghebreab, J., Havskov, J., 2004. Some features of the 1993 Bada earthquake swarm of southeastern Eritrea. Journal of African Earth Sciences 38 135-143 (288 10.1016/j.jafrearsci.2003.12.002).

Oppenheimer, C., Francis, P., 1998. Implications of longeval lava lakes for geomorphological and plutonic processes at Erta'Ale volcano, Afar. Journal of Volcanology and Geothermal Research 80, 101-111.

Pagli, C., Wright, T.J., Ebinger, C.J., Yun, S.-H., Cann, J.R., Barnie, T., Ayele, A., 2012. Shallow axial magma chamber at the slow-spreading Erta Ale Ridge. Nature Geoscience 5, 284-288 http://dx.doi.org/10.1038/NGEO1414.

Pasyanos, M., Nyblade, A., 2007. A top to bottom lithospheric study of Africa and Arabia. Tectonophysics 444 (1-4), 27-44.

Pérez-Gussinyé, M., Metois, M., Fernández, M., Vergés, J., Fullea, J., Lowry, A., 2009. Effective elastic thickness of Africa and its relationship to other proxies for lithospheric structure and surface tectonics. Earth and Planetary Science Letters 287 (1-2), 152-167.
Phipps-Morgan, J., Chen, Y., 1993. Dependence of ridge-axis morphology on magma supply and spreading rate. Nature $364,706-708$.

Pik, R., Marty, B., Carignan, J., Lavé, J., 2003. Stability of the Upper Nile drainage network (Ethiopia) deduced from (U-Th)/He thermochronometry: implications for uplift and erosion of the Afar plume dome. Earth and Planetary Science Letters 215, 73-88.

Prodehl, C., Mechie, J., 1991. Crustal thinning in relationship to the evolution of the AfroArabian rift system: a review of seismic-refraction data. Tectonophysics 198, 311-327.

Prodehl, C., Fuchs, K., Mechie, J., 1997. Seismic-refraction studies of the Afro-Arabian rift system - a brief review. Tectonophysics 278, 1-13.

Redfield, T., Wheeler, W., Often, M., 2003. A kinematic model for the development of the Afar depression and its paleogeographic implications. Earth and Planetary Science Letters 216, 383-398.

Ritsema, J., Allen, R., 2003. The elusive mantle plume. Earth and Planetary Science Letters 207, 1-12.

Ritsema, J., Deuss, A., van Heijst, H., Woodhouse, J., 2010. S40RTS: a degree-40 shearvelocity model for the mantle from new Rayleigh wave dispersion, teleseismic traveltime and normal-mode splitting function measurements. Geophysical Journal International 184, 1223-1236 http://dx.doi.org/10.1111/j.1365-246X.2010.04884.x.

Rogers, N., 2006. Basaltic magmatism and the geodynamics of the East African Rift System. Geological Society of London Special Publication 259, 77-93.

Rogers, N., Macdonald, R., Fitton, J., George, R., Smith, R., Barreiro, B., 2000. Two mantle plumes beneath the East African rift system: $\mathrm{Sr}$, Nd and $\mathrm{Pb}$ isotope evidence from Kenya Rift basalts. Earth and Planetary Science Letters 176, 387-400.

Rooney, T., Furman, T., Bastow, I., Ayalew, D., Yirgu, G., 2007. Lithospheric modification during crustal extension in the Main Ethiopian Rift. Journal of Geophysical Research 112, B10201 http://dx.doi.org/10.1029/2006JB004916.

Rooney, T.O., Bastow, I.D., Keir, D., 2011. Insights into extensional processes during magma assisted rifting: evidence from aligned scoria cones. Journal of Volcanology and Geothermal Research 201, 83-96 http://dx.doi.org/10.1016/j.jvolgeores.2010.07.019.

Rooney, T., Herzberg, C., Bastow, I.D., 2012a. Elevated mantle temperature beneath East Africa. Geology 40, 27-40 http://dx.doi.org/10.1130/G32382.1.

Rooney, T., Hanan, B., Graham, D., Furman, T., Blichert-Toft, J., Schilling, J., 2012b. Upper mantle pollution during afar plume-continental rift interaction. Journal of Petrology 53 (2), 365-389.

Rowland, J.V., Baker, E., Ebinger, C.J., Keir, D., Kidane, T., Biggs, J., Hayward, N., Wright, T.J., 2007. Fault growth at a nascent slow-spreading ridge: 2005 Dabbahu rifting episode, Afar. Geophysical Journal International 171, 1226-1246 http://dx.doi.org/10.1111/ j.1365-246X.2007.03584.

Rubin, A.M., Pollard, D.D., 1988. Dike-induced faulting in rift zones of Iceland and Afar. Geology 16, 413-417.

Schilling, J., Kingsley, R., Hanan, B., McCully, B., 1992. Nd-Sr-Pb isotope vari- ations along the Gulf of Aden: evidence for Afar mantle plume-continental litho-sphere interaction. Journal of Geophysical Research 97, 10,927-10,966.

Shillington, D.J., Scott, C.L., Minshull, T.A., Edwards, R.A., Brown, P.J., White, N., 2009. Abrupt transition from magma-starved to magma-rich rifting in the eastern Black Sea. Geology 37, 7-10.

Simmons, N., Forte, A., Grand, S., 2007. Thermochemical structure and dynamics of the African superplume. Geophysical Research Letters 34 (2) http://dx.doi.org/10.1029/ 2006GL028009.

Souriot, T., Brun, J.-P., 1992. Faulting and block rotation in the Afar triangle, East Africa: the Danakil "crank-arm” model. Geology 20, 911-914.

Stamps, D.S., Calais, E., Saria, E., Hartnady, C., Nocquet, J.-M., Ebinger, C.J., Fernandes, R.M., 2008. A kinematic model for the East African rift. Geophysical Research Letters L05304 http://dx.doi.org/10.1029/2007GL032781.

Storey, M., Duncan, R.A., Tegner, C., 2007. Timing and duration of volcanism in the North Atlantic Igneous Province: implications for geodynamics and links to the Iceland hotspot. Chemical Geology 241, 264-281.

Stork, A.L., Stuart, G.W., Henderson, C.M., Keir, D., Hammond, J.O.S., in review. Uppermost mantle $(\mathrm{Pn})$ velocity model for the Afar region, Ethiopia: An insight into rifting process. Geophysical Journal International.

Stuart, G.W., Bastow, I.D., Ebinger, C.J., 2006. Crustal structure of the northern Main Ethiopian Rift from receiver function studies. Geological Society of London Special Publication 259, 253-267.

Talbot, C.J., 2008. Hydrothermal salt - but how much? Marine and Petroleum Geology 25, 191-202 http://dx.doi.org/10.1016/j.marpetgeo.2007.05.005.

Tapponnier, P., Armijo, R., Manighetti, I., Courtillot, V., 1990. Bookshelf faulting and horizontal block rotations between overlapping rifts in southern Afar. Geophysical Research Letters 17, 1-4 (0.1029/GL017i001p00001).

Tazieff, H., Varet, J., Barberi, F., Giglia, G., 1972. Tectonic significance of the Afar (or Danakil) depression. Nature 235, 144-147.

Tesfaye, S., 2005. Fault population investigation and estimating magnitude of extension in Guma Graben, Central Afar, Ethiopia. Journal of African Earth Sciences 41, 437-444 http://dx.doi.org/10.1016/j.jafrearsci.2005.05.002.

Tesfaye, S., Harding, D.J., Kusky, T.M., 2003. Early continental breakup boundary and migration of the Afar triple junction. Geological Society of America Bulletin 115, 1053-1067.

Tesfaye, S., Rowan, M.G., Mueller, K., Trudgill, B.D., Harding, D.J., 2008. Relay and accommodation zones in the Dobe and Hanle grabens, central Afar, Ethiopia and Djibouti. Journal of the Geological Society 165, 535-547 http://dx.doi.org/10.1144/ 0016-76492007-093.

Tessema, A., Antoine, L.A.G., 2004. Processing and interpretation of the gravity field of the East African rift: implication for crustal extension. Tectonophysics 394, 87-110 http://dx.doi.org/10.1016/j.tecto.2004.07.057.

Thurmond, A.K., Abdelsalam, M.G., Thurmond, J.B., 2006. Optical-radar-DEM remote sensing data integrated for geological mapping in the Afar Depression, Ethiopia. Journal of African Earth Sciences 44, 119-134 http://dx.doi.org/10.1016/ j.jafrearsci.2005.10.006. 
Thybo, H., Nielsen, C.A., 2009. Magma-compensated crustal thinning in continental rift zones. Nature 457, 873-876 http://dx.doi.org/10.1038/nature07688.

Tiberi, C., Ebinger, C., Ballu, V., Stuart, G., Oluma, B., 2005. Inverse models of gravity data from the Red Sea-Aden-East African rifts triple junction zone. Geophysical Journal International 163, 775-787.

Ukstins, I.A., Renne, P.R., Wolfenden, E., Baker, J., Ayalew, D., Menzies, M., 2002. Matching conjugate volcanic rifted margins: Ar/Ar chronostratigraphy of preand syn-rift bimodal flood volcanism in Ethiopia and Yemen. Earth and Planetary Science Letters 198, 289-306 http://dx.doi.org/10.1016/S0012-821X(02)00525-3.

Vigny, C., Huchon, P., Ruegg, J.-C., Khanbari, K., Asfaw, L.M., 2006. Confirmation of Arabia plate slow motion by new GPS data in Yemen. Journal of Geophysical Research 111, B02402 http://dx.doi.org/10.1029/2004JB003229.

White, R., 1988. A hot-spot model for early tertiary volcanism in the N Atlantic. Geological Society of London Special Publication 39 (1), 3-13.

White, R.S., McKenzie, D.P., 1989. Magmatism at rift zones: the generation of volcanic continental margins and flood basalts. Journal of Geophysical Research 94, 7685-7729.

White, R.S., Smith, L.K., Roberts, A.W., Christie, P.A.F., Kusznir, N.J., The iSIMM Team, 2008. Lower-crustal intrusion on the North Atlantic continental margin. Nature 452, 460-464 http://dx.doi.org/10.1038/nature06687.

Whitmarsh, R.B., Manatschal, G., Minshull, T.A., 2001. Evolution of magma-poor continental margins from rifting to seafloor spreading. Nature 413, 150-154.
Williams, F.M., Williams, M.A.J., Aumento, F., 2004. Tensional fissures and crustal extension rates in the northern part of the Main Ethiopian Rift. Journal of African Earth Sciences 38, 183-197.

WoldeGabriel, G., Aronson, J.L., Walter, R.C., 1990. Geology, Geochronology, and rift basin development in the central sector of the Main Ethiopian rift. Geological Society of America Bulletin 102, 439-458 http://dx.doi.org/10.1130/0016-7606(1990) 102<0439:GGARBD>2.3.CO;2.

Wolfenden, E., Ebinger, C., Yirgu, G., Deino, A. Ayelew, 2004. Evolution of the northern Main Ethiopian rift: birth of a triple junction. Earth and Planetary Science Letters 224, 213-228 http://dx.doi.org/10.1016/j.epsl.2004.04.022.

Wolfenden, E., Ebinger, C., Yirgu, G., Renne, P.R., Kelley, S.P., 2005. Evolution of a volcanic rifted margin: southern Red Sea, Ethiopia. Geological Society of America Bulletin 117, 846-864 http://dx.doi.org/10.1130/B25516.1.

Wright, T.J., Biggs, J., Ayele, A., Yirgu, G., Keir, D., Stork, A., 2006. Magma-maintained rift segmentation at continental rupture in the 2005 Afar dyking episode. Nature 442, 291-294 http://dx.doi.org/10.1038/nature04978.

Wright, T.J., Sigmundsson, F., Pagli, C., Belachew, M., Hamling, I.J., Brandsdottir, B., Keir, D., Pedersen, R., Ayele, A., Ebinger, C., Einarsson, P., Lewi, E., Calais, E., 2012. Geophysical constraints on the dynamics of spreading centres from rifting episodes on land. Nature Geoscience 5, 242-250 http://dx.doi.org/10.1038/NGEO1428. 